$$
\text { الحرب اللأهلية فى سيراليون }
$$

\title{
The civil war in Sierra Leone
}

\section{شريف محمد على البريرى -معهد البحوث والدراسات الأفريقيه القاهرة}

Available online at https://www.maspolitiques.com/ojs/index.php/ajps/article/view/139

\begin{abstract}
:
Physical oppression and coercion against the Sierra Leone people, the government's inability to hold those involved in theft and looting of the country's wealth and the trend towards establishing a pattern of personal rule that gives great importance to the role of the ruling person in the political system and the non-recognition of organized political opposition, and considering it a matter that does not fit the African reality to emphasize the concept One political party The developmental state was unable to provide the basic needs of the people, as the ruling party contributed to the resort of Sierra Leone after the British colonial period to imposing a developmentist ideology based on the interconnected political and economic processes And given the collapse of the raw material markets and the use of policies to erode state legitimacy, the prevalence of conflict phenomena, and political and economic instability in society.
\end{abstract}

Key words: repression, establishment, African, war, Sierra Leone. 
القمع والإكراه المادى ضد الثعب السيراليونى وعدم قدرة الحكومة على محاسبة المتورطين فى أعمال السرقة والنهب لثروات البلاد والاتجاه نحو تأسيس نمط من الحكم الثخصي الذى يعطى أهمية كبرى لدور شخص الحاكم في النظام السياسي وعدم الاعتراف بالمعارضة السياسية المنظمة، واعتبارها مسألة لا تلائم الواقع الأفريقي للتأكيد على مفهوم الحزب السياسي الواحد عجزت الدولة التتموية على توفير الاحتياجات الأساسية للشعب، إذ أسهم الحزب الحاكم في لجأت سيراليون بعد فترة الاستعمار البريطانى إلى فرض الأيديولوجية التتموية التي ثقوم على ترابط العمليتين السياسية والاقتصادية، ونظراً لإنهيار أسواق المواد الخام واستخدام سياساتتاكل شرعية الدولة، وشيوع ظاهرة الصراعات، وعدم الاستقرار السياسي والإقتصادى فى المجتمع. الكلمات المفتاحية:قمع،تأسيس،افريقي،حرب،سيراليون. 


$$
\begin{aligned}
& \text { أولا:موضوع الدراسة: } \\
& \text { الحرب الأهلية فى سيراليون: }
\end{aligned}
$$

منذ عام 1991 شـهـت سيراليون حربـا أهلية شرسـة مـع حركة التمرد الثوري والجبهة المتحدة برئاسـة



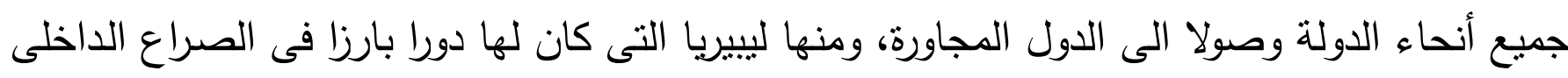
لسيراليون، واشتـعل الصـراع مـن خـلاه الدعم العسكري الخـارجي لبعض الأطراف المتنازعـة، وإشـراك المرتزقة الأجانب والميليشيات الخاصـة فى عملية الصراع على السلطة السياسية، وقد دعمت ليبيريا، وبوركينا فاسو، وليبيا الجبهة المتحدة الثورية بلأسلحة والمعدات اللازمة من أجل السبطرة على الموارد

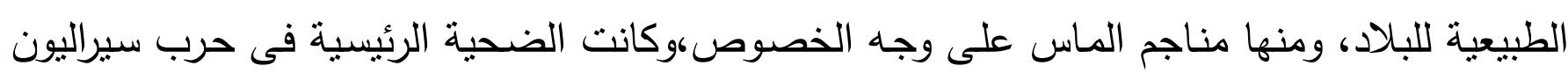
هم المدنيين الذين عانوا من النهب والسرقة والتشويه والقتل من عصابات التمرد والمرتزقة، وكانت عملية التسوية صسبة بسبب الدعم الخـارجى لقوى المعارضـة (الجبهة المتحدة التوريـة) حيث كانت مواقفها السياسية غير واضحة في عملية نزع السـلاح وتسريح الجيش، إذ كان هناك انتهاكات مستمرة لوقف

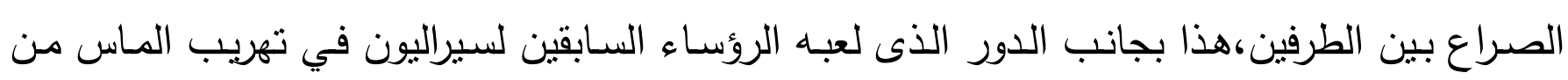

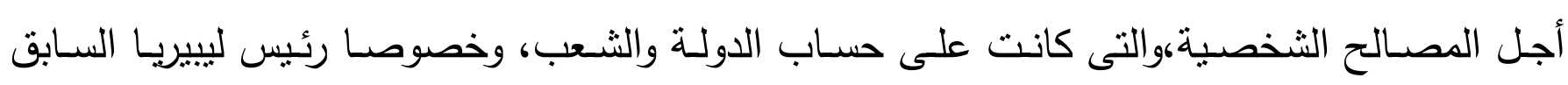
تشارلز تايلور الذي اتهمته محكمة دولية بنلك التهمة في عام .2004 أ -

ثانيا:مشكلة الدراسة: لجأت سيراليون بعد فترة الاستعمار البريطانى إلى فرض الأبديولوجية التنموية التي

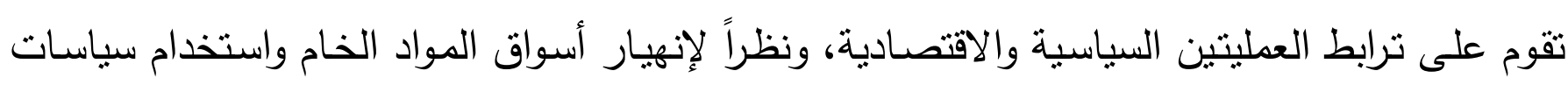
القع والإكراه المادى ضد الثعب السيراليونى، وعدم قدرة الحكومة على محاسبة المتورطين فى أعمال السرقة والنهب لثروات البلاد، والاتجاه نحو تأسيس نمط من الحكم الثخصي الذيى يعطى أهمية كبرى لدور شخص الحاكم في النظام السياسي وعدم الاعتراف بالمعارضة السياسية المنظمة، واعتبارها مسألة لا تلائم الواقع الأفريقي للتأكيد على مفهوم الحزب السياسي الواحد، عجزت الدولة التتموية على توفير

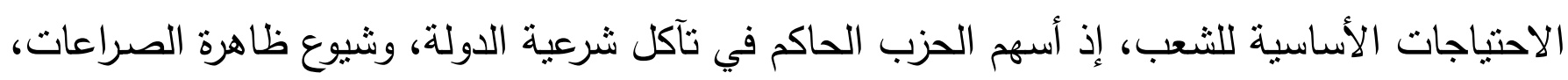






\section{ثالثا:أهمية الدراسة: \\ - 1- الأهمية العلمية:}

تتلخص الأهمية العلمية لهذه الدراسـة فى مناقتـة الأسباب الرئيسية التى أدت الى الحرب الأهلية فى

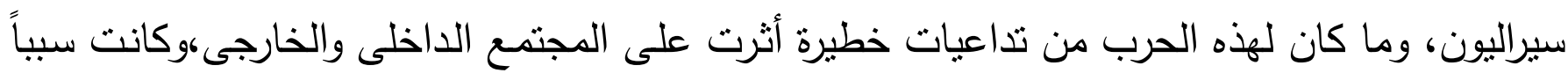
فـى نقل عـدوى الحـرب الـى الـدول المجـاورة، وإثـتعال الصـراع الإقليمسى ممـا ترتبـ عليـهـ الإنهيـار الإقتصادى والإجتماعى لبعض هذه الدول.

- 2الأهمية العملية:

تساهم هذه الدراسة فى إضافة بعض المعلومات اللازمة فى كيفية الخروج من الأزمات

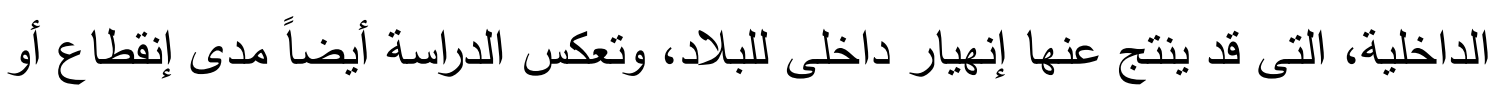

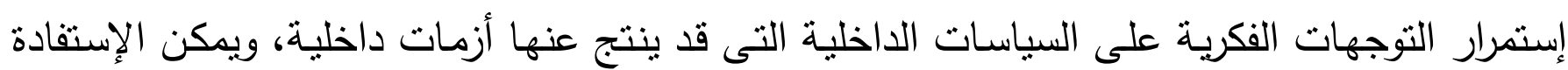

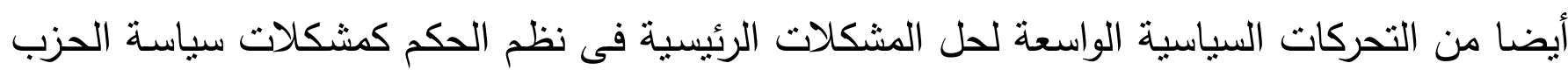

$$
\text { الوابعا:الإطار الزم عدم قبول الرأى الأخر. }
$$

بدأت الحرب الأهلية فى سيراليون عام 1991 بعد أن تآكلت السلطة المركزيـة وعجز الحزب الحاكم على وقف أعمال السرقة والنهب لموارد الدولة وبخاصسة عمليات تهريب الماس الذى يمثل أهم مصسادر لهار الدخل للاولة إذ بدأت الصراعات الأهلية والإنقابات العسكرية للسيطرة على الحكم وعلى حقول الماس

$$
\begin{aligned}
& \text { والتى انتهت فى عام } 2002 . \\
& \text { خامسا:التساؤلات والفروض: } \\
& \text {-1التساؤل الرئيسى: } \\
& \text { أ)ماهى أسباب الحرب الأهلية فى سيراليون؟ } \\
& \text {-2التساؤلات الفرعية: }
\end{aligned}
$$

أ)ما هى طبيعة السياسة الداخلية والخارجية للدولة؟

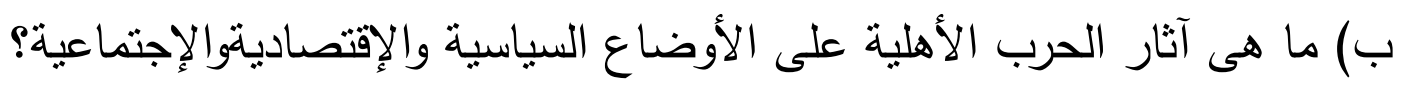

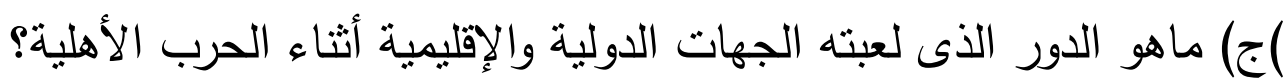




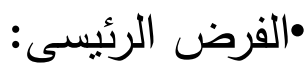

عدم استيعاب أكبر قدر من القوى المعارضـة أدى إلى اشتعال فتيلة الصراع الداخلى،هذا بجانب العجز على تحقيق هدفى التوزيع العادل للثروة وافتقادها القدرة على حشد تأييد الثرعية السياسية والاجتماعية.



•استخدام سياسة الحزب الواحد وعدم الإعتراف بالتعددية الحزبية أدى الى مزيد من السخط

الثعبى الداخلى، هذا بجانب التذخل الخارجى الذى كان سببا فى شدة الإنفجار .

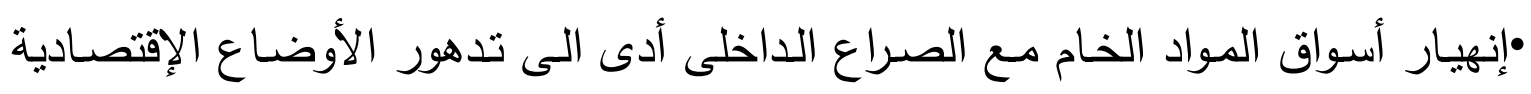

$$
\text { والسياسية والإنسانية في سيراليون. }
$$

•تضافرت الجهود الدولية والإقليمية لوضع حد للحرب الدائرة بين قوات الحكومة وقوات

$$
\text { المتمردين بعد التهديد المباشر لمصالحهم الداخلية فى سيراليون. }
$$

سادساً:الأدبيات السابقة:

1- Alfred Bzack-williams,"Sierraleon the political economy of civil,19911998",third world Quartely (Londn:Taylor \& Francis, Ltd , Vol.20,no.1,1999).

تتاقش هذه الورقه تأثثر الحرب الأهليه على الوضع السياسى والاقتصادى لدولة سبراليون إذ تم تدمير

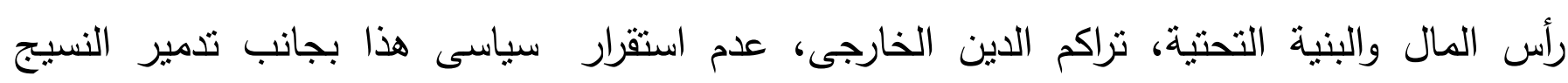
الاجتماعي وتهديد الحريات المدنية ،انتشار النزاعات المسلحة في المناطق الغنيه بالماس للسيطرة

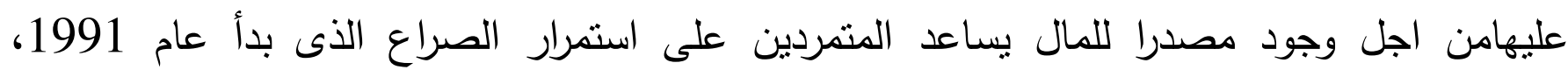
إذعانت البلاد الحرب والرعب ، وأزمة إنسانية أحدثت شرخا كبيرا فى قلوب الأطفال والنساء من شدة ما

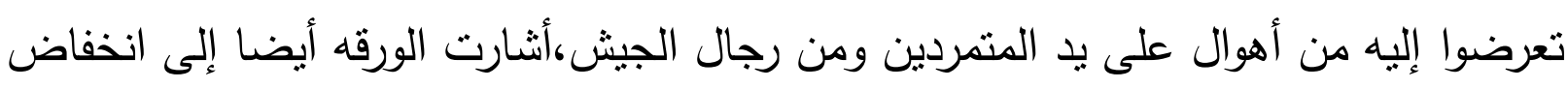

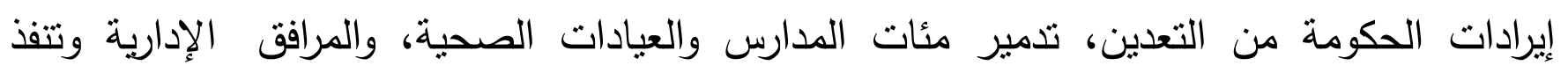
التهجير القسري لأكثر من نصف عدد السكان تقدر ب 4.5 مليون نسمة. وقتل ما بين 20،000 و و

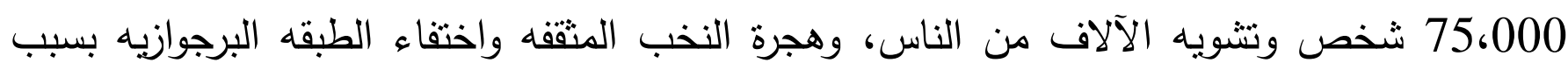
الحرب الأهليه، وتدمير المدارس التعليمية ليصبح الطفل جندى بدلا من ان يكون طالبا للعلموأيضا نوهت الورقه على إستخدام أو إنشاء الحزب الواحد الذى يعرف بإسم حزب الشعب الكلى(دولة الظل) 


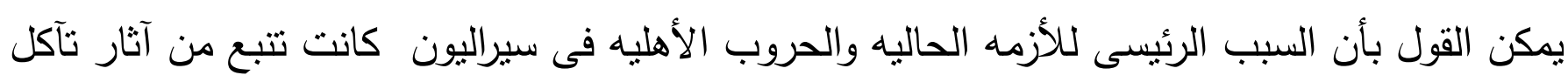

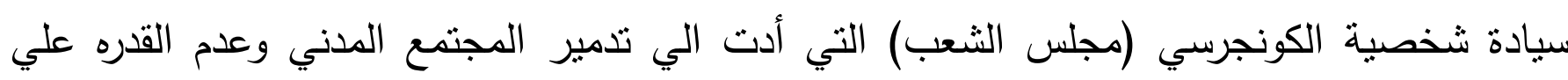

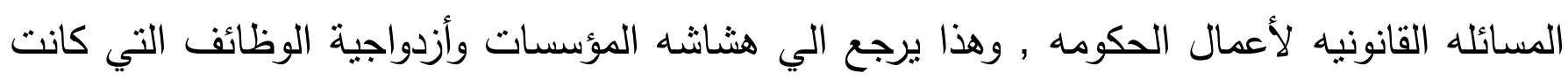

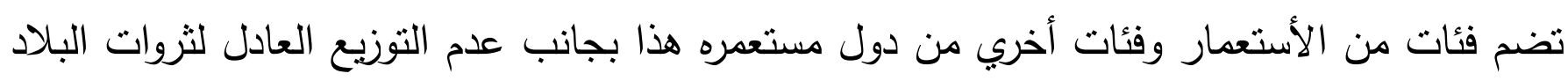

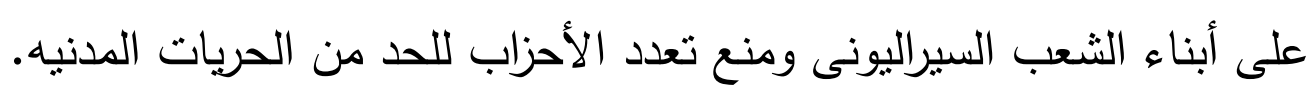
2-Philippe Le Billon"The Political ecology of war:natural resources and armed conflicts"Political Geography(Elsevier- Sience Ltd,Vol.20,no,5,2001). تثير الورقه إلى الحروب الأهلية التى أوجدت نتائج شديدة الخطورة على الدولة و يعد انهيار الدولة

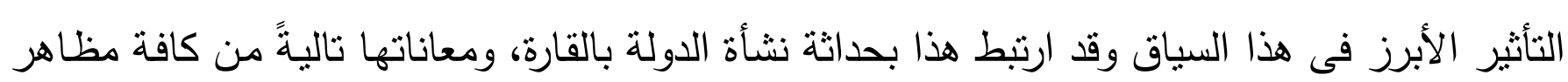

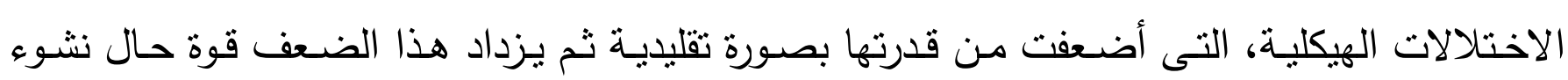

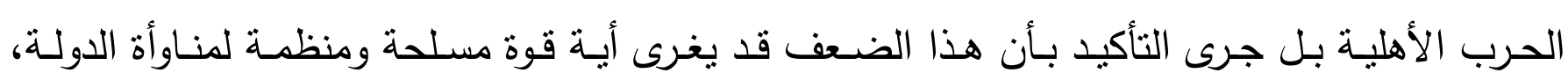

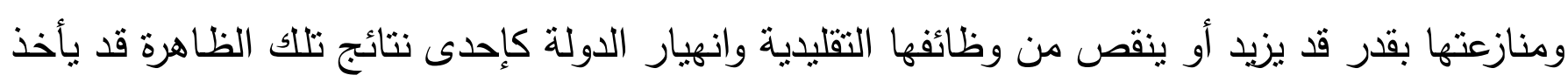

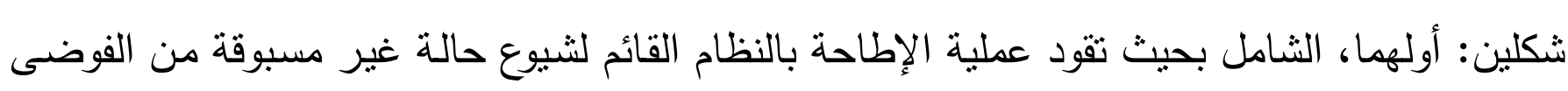

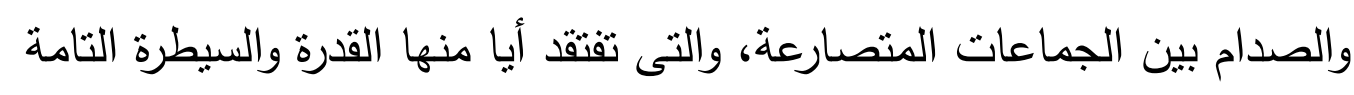





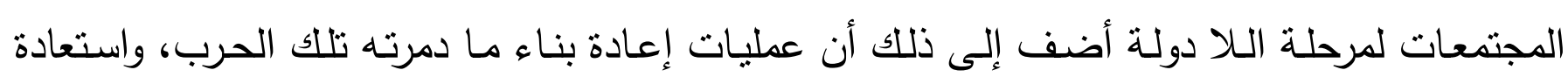

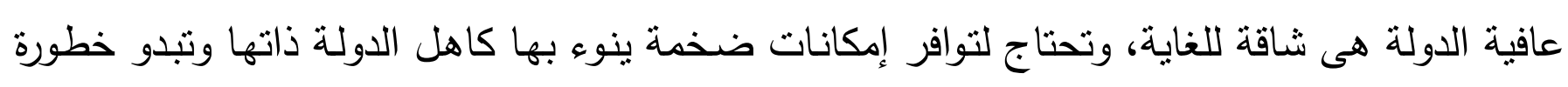
هذا الانهيار فى كونه يقود إلى تفنتيت الوحدة الجغرافية والثقافية للاولة الواحدة للعديد من الكيانات



$$
\text { منهم يسمح بتواجد الآخر فى المجتمع الواحد. }
$$

يعتبر التحدى الرئيسى هنا يتمثل فى شيوع حالات عدم الاستقرار الداخلى، مما يعنى أن الديموقراطية

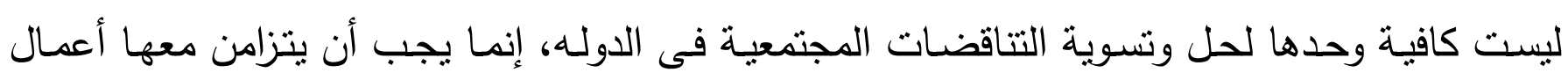

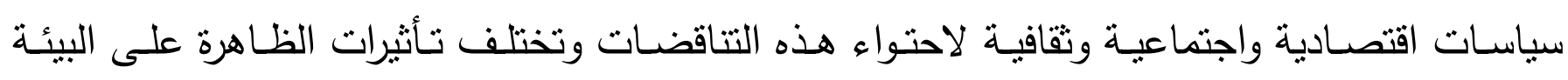

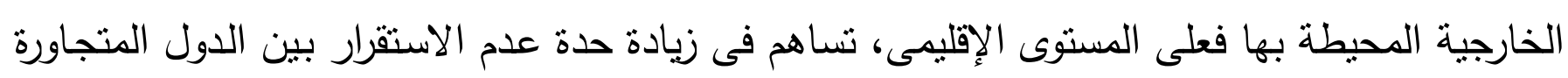

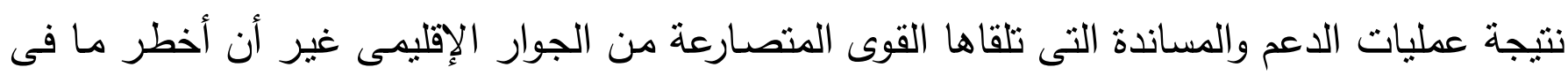


هذا التأثثر هى عدوى الحروب بين الدول، نتيجة لنيوع مناخ عام من عدم الاستقرار الإقليمى ومثل تلك

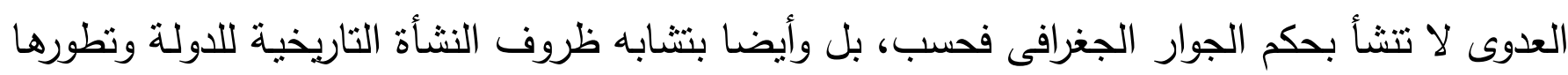

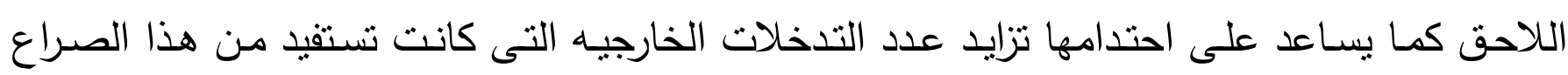

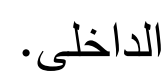

3- Joseph Hanlon "Is the International Commuity Helping to Recreate the Pre-Conditions for -D War in Sierr Leone" UNU World Institute for Development Economics Research", United Nations University, Helsinki, Finland,no.50,2005))

تثير هذه الورقة الى دور الماس فى الحرب الأهلية وكيف تم توظيفه فى ادارة الصراع ،هذا بجانب

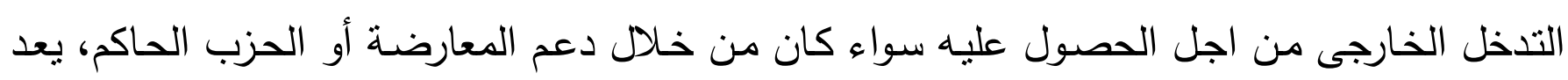

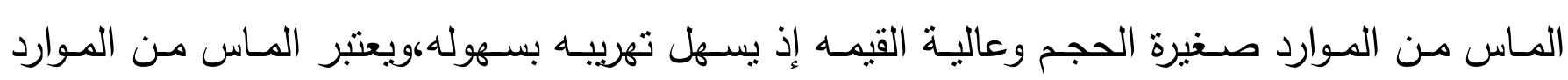

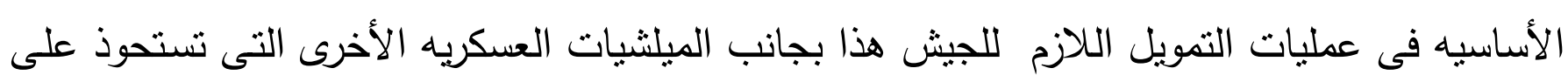

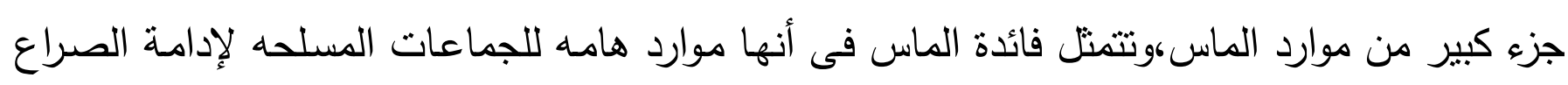

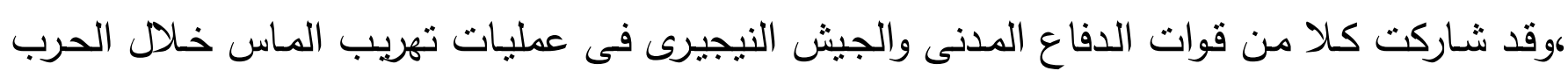

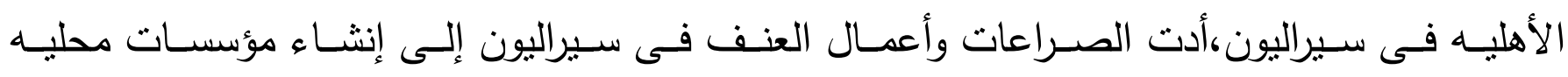

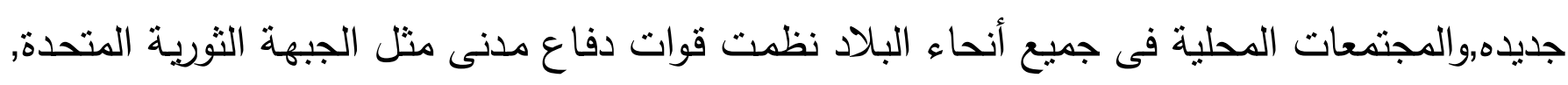

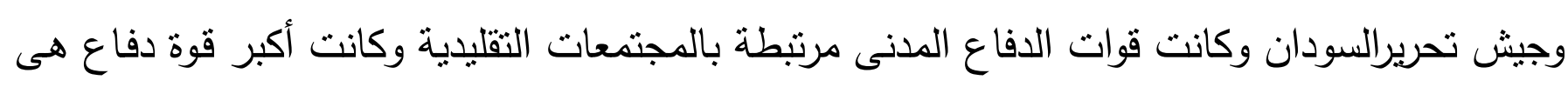

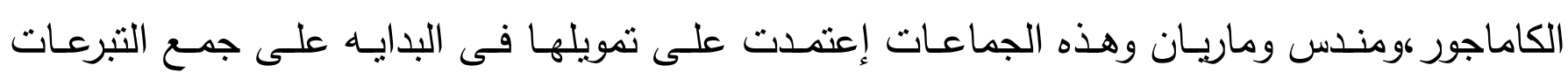

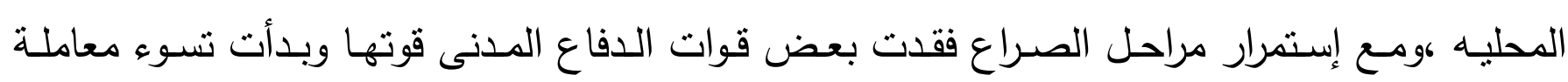

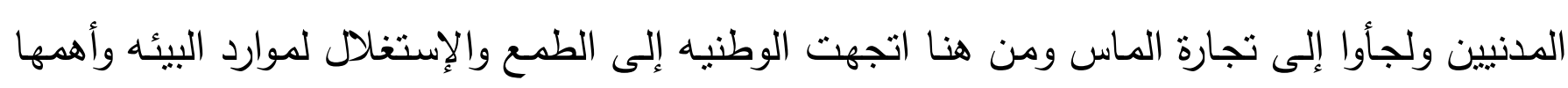
الماس الذى يعد اهم مصادر التمويل الغير رسمى.

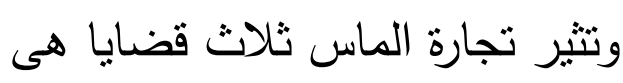
-1 هو حجم هذه التجارة وحجم الأموال المخصصه للمنمردين (تقدر قيمة دخل الماس سنويا بـ300

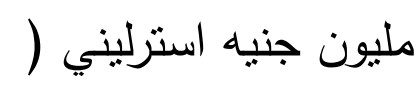
-2نقص المعلومات الحقيقيه عن المناجم وعن حجم تجارة الماس الفعلى في سيراليون 
-3مع الأخذ في الإعتبار أن العاملين الأول والثاني هما عدم الإهتمام العالمي الكافي بهذا المصدر

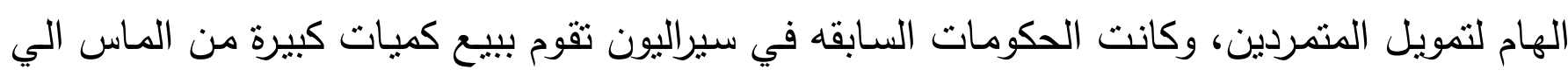

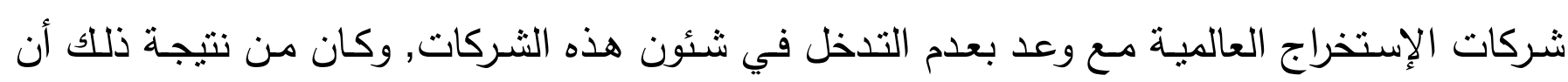

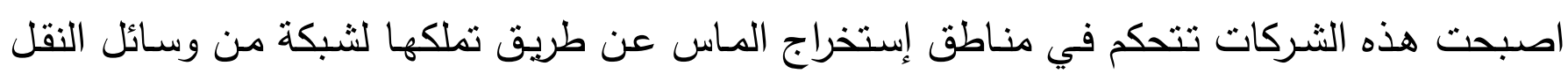
والإتصال المحكمه، وكانت شركات إستخراج الماس تشتعين بشركات الأمن الخاصه لحماية مصالحها. المبحث الأول

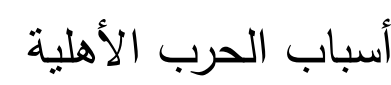

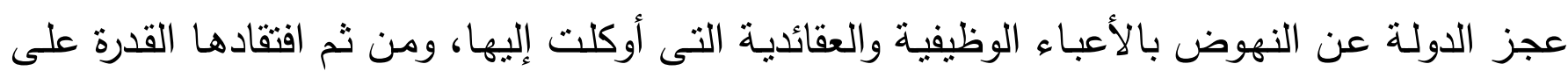

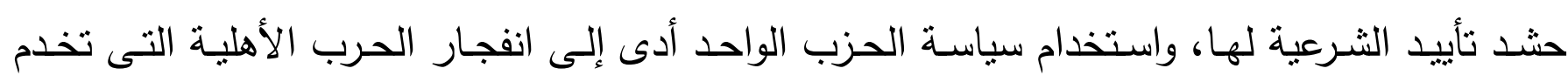
غايات ومصالح جماعات داخلية وخارجية على حساب الوضع السياسى والإقتصادى للبلاد. المطلب الأول: الصراع على السلطه : مما يلفت الإنتباه الدور الذى لعبته الثخصيات الحاكمة لقيادة أسياد الدحيط الهادى، والعوامل الهيكلية

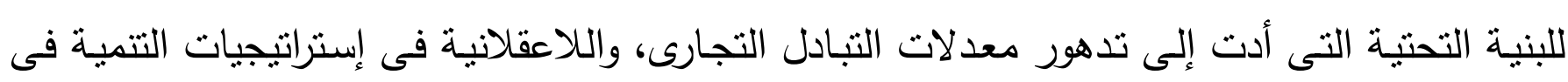

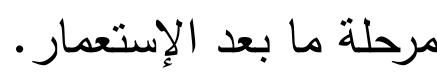

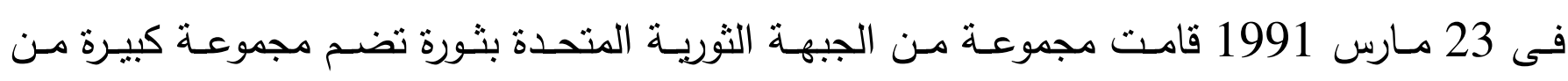

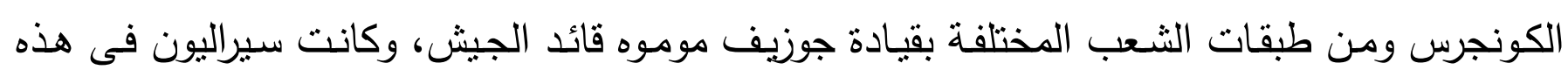

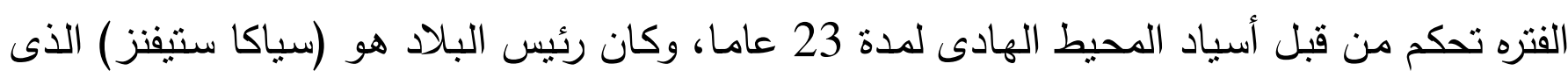

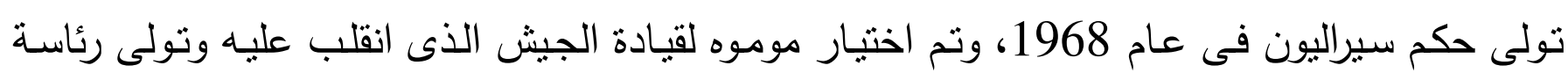

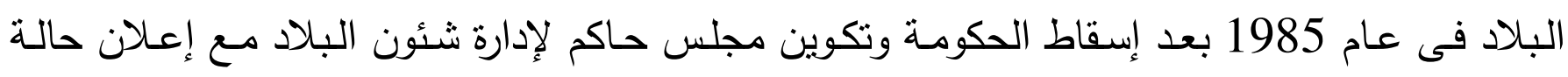

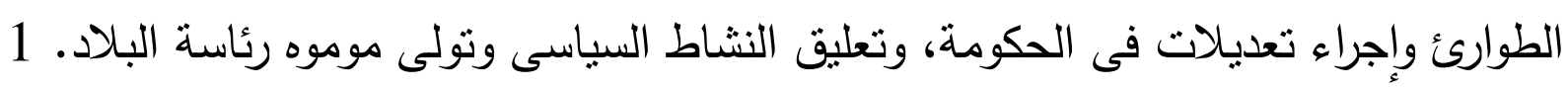

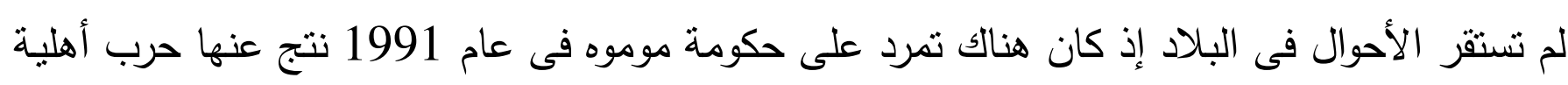

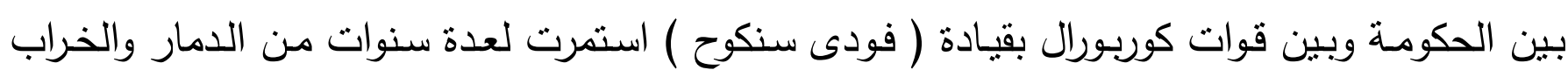
على الثُب وعلى اقتصاد الدولة، واتهمت الحكومة المتمردين بالتعسف الخطير ضد التد حقوق الإنسان وانتهاك سيادة الدولة والقانون.1. عندما وصل موموه للسلطة كان يتمتع بشعبية كبيرة حيث انعقدت عليه الآمال في إصـاح الفساد




تصديره الي 48 ألف قيراط عام 1988 بعد أن كان مقداره 20 مليون قيراط عام 1970 وذلك بسبب سوء الإدارة والفساد وليس بسبب نقص موارد مناجم الماس. وتميز عهد "موموه" ببروز ظاهرتين: الأولي هي ارتفاع معدل البطالة وتدفق الثباب للعمل في العاصـة أو المراكز الحضرية أو للعمل بمناجم الماس في كونو، وفي كل الأحوال انخرط هؤلاء في حياة العنف والجريمة والمخدرات، والظاهرة الثانية هي ازدياد أعداد الطلاب الذين انضموا للميليشيات العسكرية، بدأ موموه يفقد قدرته على التحكم فى إدارة

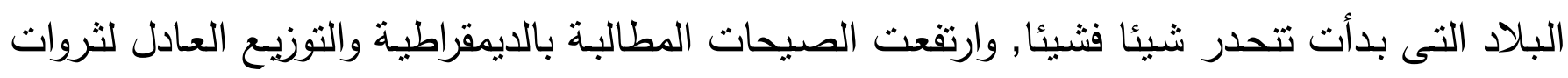
البلاد، إستغل (فرنسيس مناح ) ضعف شعبية موموه وقام بعدل إنقلاب عليه على الرغم من أنه كان من الموالين له أثناء إنقلابه على سياكا ستيفنز إذ كان مناح من ضاحية (بوجيهون) وهى واحدة من أهم أهم المناطق التى كانت فى خط الجبهة الأمامية أثثاء الحرب الأهلية. 2 فنشل فرنسيس مناح فى عملية الإنقلاب على موموه وتم إستبعاده من الإنتخابات الرئاسية

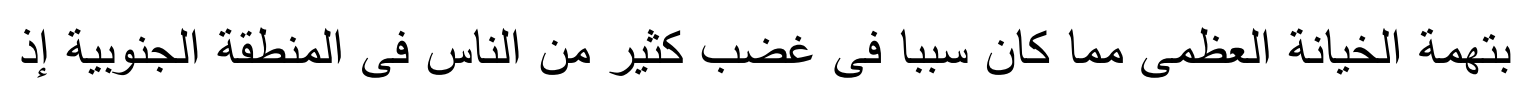

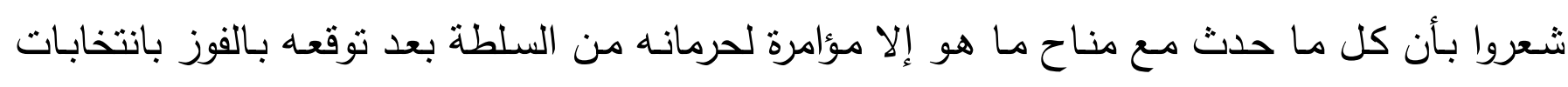
الرئاسة، قامت مجموعة من دول القارة الإفريقية بالضغط على حكومـة موموه بعد فنشل الإنقلاب عليه لإجراء إنتخابات متعددة الأحزاب وتحقيق الديمقرطية والإستجابة للمطالب الثعبية التى طالب بها كل من مجتمع الجامعة وأطفال المدارس والعاطلين عن العمل مقادة برابطة (BAR)، وكانت استجابة موموه لهذه المطالب أن حولها إلى النائب العـام (كامـار) الذى حذر المعارضــــ مـن الحديث حـول تعدديـة الأحزاب والديمقراطية لأن ذلك مخالف للقانون فى حالة الحزب الواحد للدولة ومن يخالف سيقع تحت

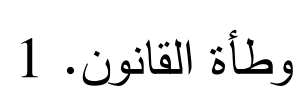

وبحلول عام 1991 كان نظام موموه يواجه صعوبات خطيرة, ودعا موموه الي العودة للأخذ بنظام تعدد الأحزاب, وتم الإعداد للإنتخابات عام 1992. إلا أنه قبل بدء الإنتخابات المرتقبة قامت الجبهة الجهة الثورية المتحدة (ruf)بزعامة "فوداي سنكوح" وبتأييد ومساعدة من ليبيريا بمهاجمة الإنظمة الثرقية والجنوبية

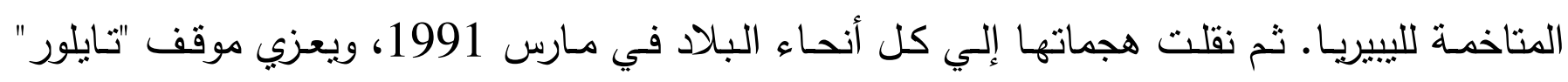

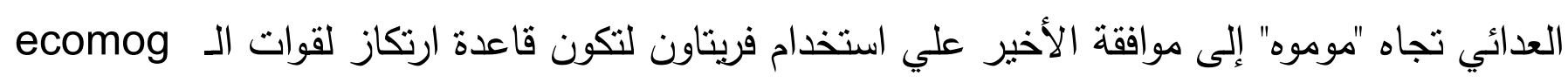

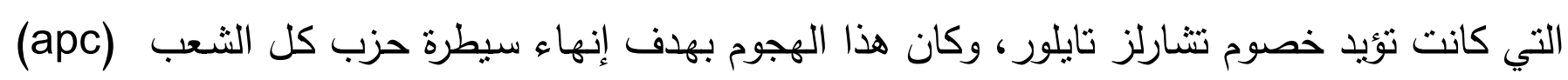
علي الحكم لمدة 24 عاما ونتيجة لحدوث الفساد بسبب إساءة استخدام السلطة وعدم دفع رواتب أفراد القوات 
المسلحة الموجودين على خطوط الجبة الأمامية في سيراليون, سافرت مجموعة من الجبهة الثرقية إلى فريتاون لعرض مطالبها, وحدث إنقلاب عسكري عام 1992 بقيادة " فالنتين ستراسر" البالغ من العمر

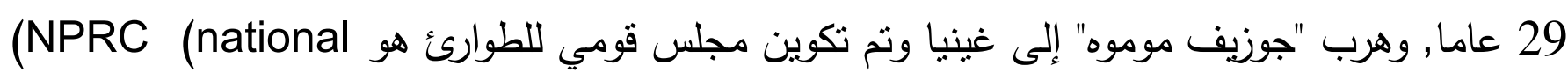

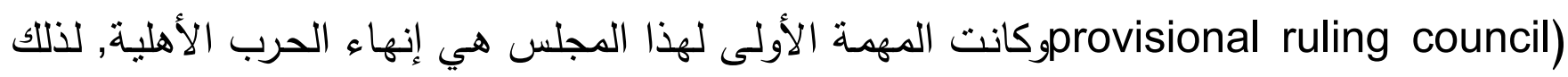
قام بمضاعفة عدد القوات المسلحة من ثلاثة آلاف إلى 16 ألف في الفترة من (1992 1994). "تراسر" بإنهاء حركة المتمردين في الجنوب خلال عام واحد, ووعد بإعادة الديمقراطية للبلاد , الا انه لم يستطع تحقيق اي نجاح , بل اتسع نطاق المنطقة التي يسيطر عليها المتمردين , وابتلع الانفاق علي

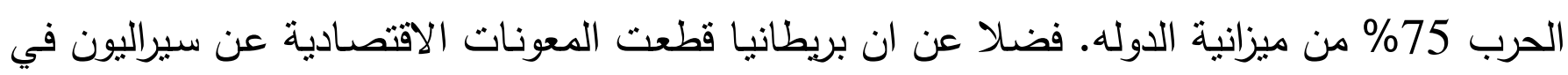
يناير 1993, بسبب اقدام "ستراسر" علي اعدام عددا من المعارضين, مما اجبره علي تبني برنـامج التحول للتعددية الحزبية.1. وتحت ضغط قوي من الوكالات المانحسه ومن الثـعب لكي يعود الحكم المدني الي سبراليون اعلنت انسه سيتم اجراء انتخابات في فبراير 1996 , وبدا ستراسر في اتخاذ الخطواط لتسليم الحكم للمدنيين وحدد موعدا للأنتخابات في فترة لاحقه , إلا أنه أراد التنازل عن رتبته العسكرية وترشيح نفسه في الانتخابات مما اثار ضغنية رجال الجيش عليه , فقاموا بأنقلاب عسكري بقيادة نائبه البريجادير "جوليوس مادابيو وكانت الجبهة الثورية المتحدة عUF اعلنت وقف اطلاق النار بعد هزيمتها علي يد القوات المساندة للحكومة وتم ابعادهم عن مناطق استخراج الماس , وواصلت محادثات السلام مع حكومة " جوليوس مادابيو" في

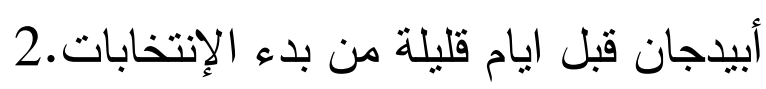
تمت الجولة الأولي للأنتخابات في 26 , 27 يناير 1996 والتي اشتنرك فيها 13 حزبا سياسيا, وبسبب عدم حصول اياً من هذه الاحزاب علي نسبة 55\% لكي تتولي الحكم تم اعادة الأنتخابات بين الحزبين

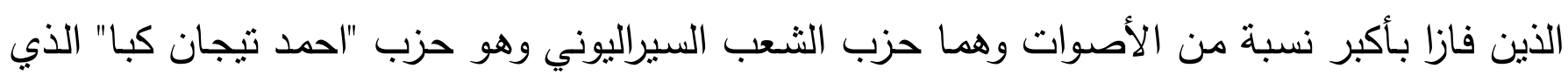

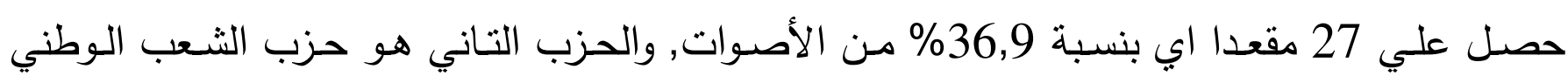

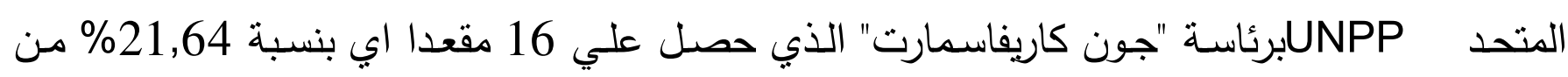
الأصوات ـ وفي الجولة الثانية من الأنتخابات التي جرت في 15 مارس 1996 فاز حزب "احمد تيجان

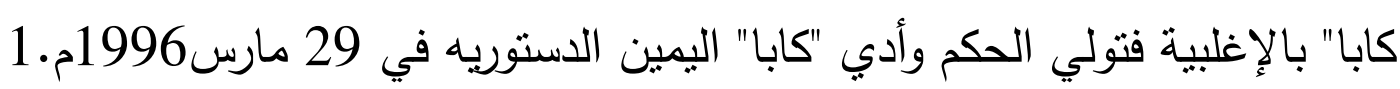


وبذلك ينتين أنه عندما تولي الرئيس كابا الحكم عام 1996 كانت سيراليون شبه خاليه من مظاهر قوة



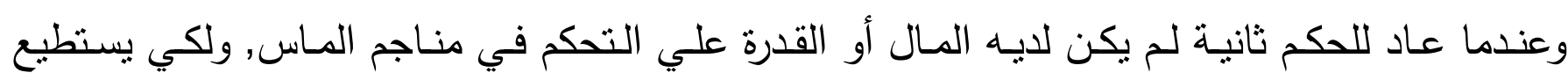

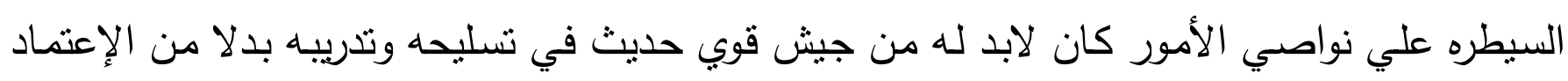

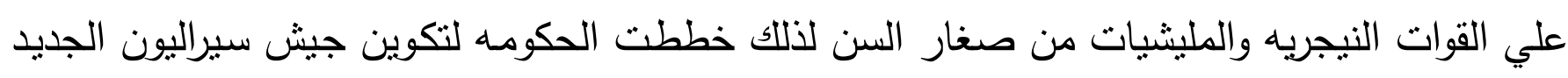

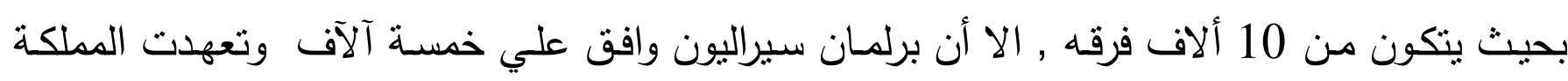

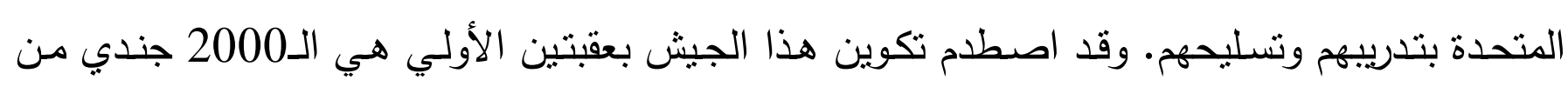

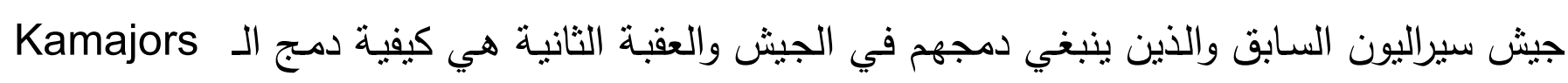

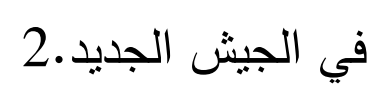
وفى يناير 1998بدأت حكومة كباح فى محاكمة هدبرى الأنقلاب ومن بينهم فوى سنكوح، وصدر الحكم

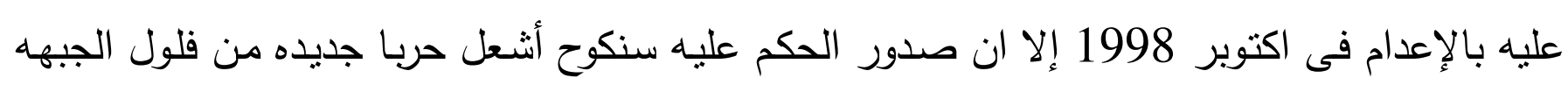

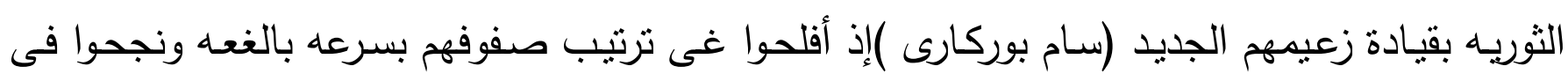

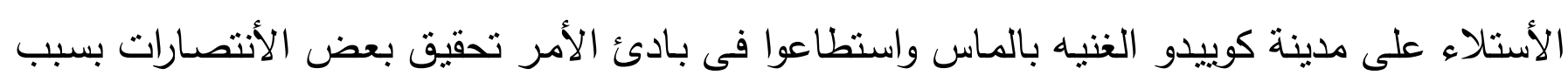

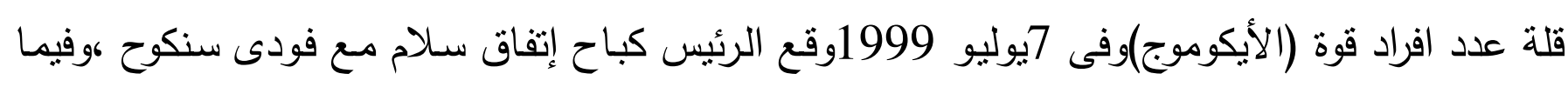



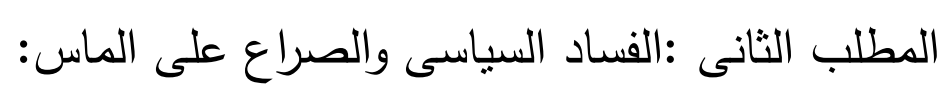

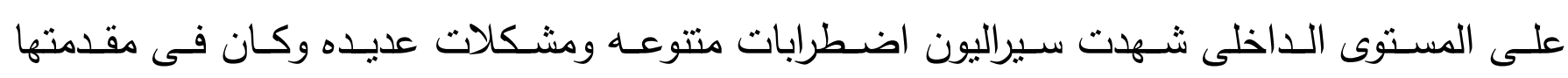

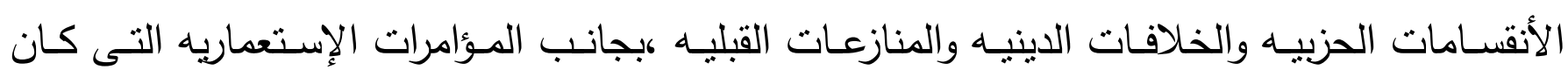

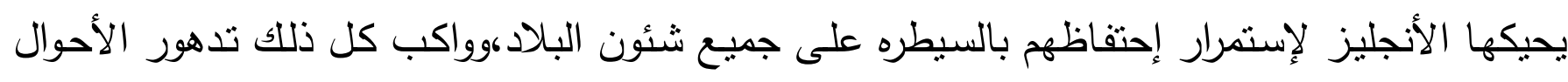

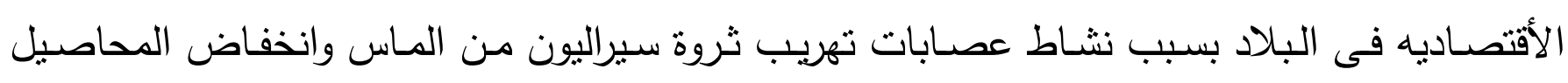

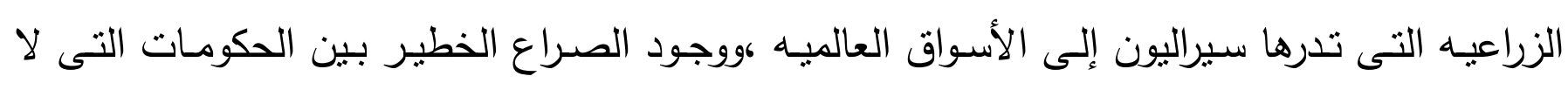
نحقق لهم اهدافهم ليسهل لهم استنزاف موارد البلاد وثرواتها. أولا الفساد السياسى: كان عجز الحكومات عن حل هذه الشكلات من العوامل الرئيسيه التى دفعت بعض العسكريين الى الى العيات

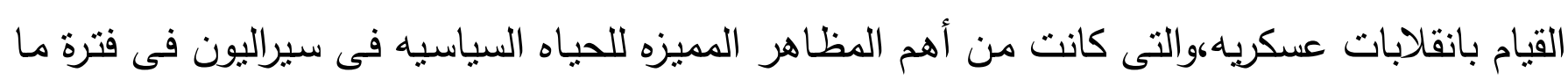
بعد الأستقلال حيث تعرضت سيراليون لسبعة إنقابات عسكريه ومحاولتين إنقلابيتين فانظلتين وحدوث 
عنف عنصرى بين أكبر قبيلتين فيها هما قبيلتى مندى وتمنى فى ديسمبر 1968 م وإندلاع مظاهرت

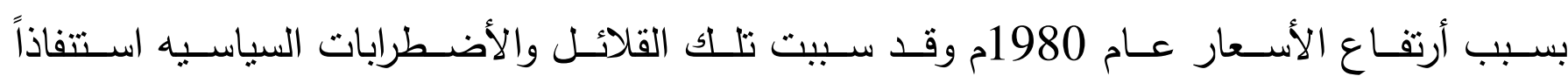
لجهودالتنميه. أثنـار كانديـه فى كتاباته عن الطبقه الحاكمـه فى سيراليون أنها أثتبتت عجزهـا عن الأمتثال بالثـرعيه الدوليه فى عدم إقامة مشروعها الذى يعرف بمشروع (الدوله المهيمنه)إذ يقوم هذا المشروع عى اساس

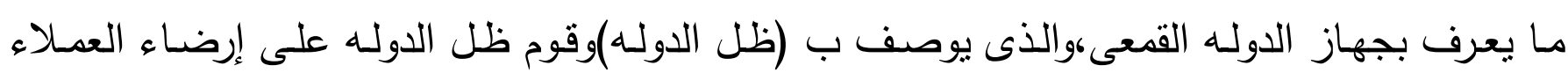
بواسطة تحرير الأصول والفوائد على القروض ومصادرة الإرادات من المناطق الريفيه عن طريق موظفى بلى لإنى

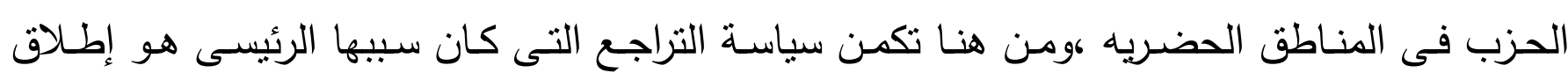

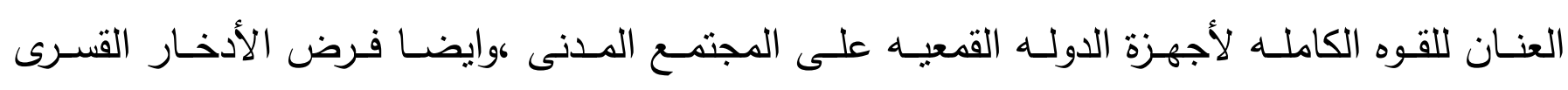
(الجبرى)على الفلاحين والعمال عبر التسويق مسيطر عليه مجلس الدوله السيراليونى. يعد السبب الرئيسى للأزمه الأقتصاديه والحروب الأهليه فى سبراليون يرجع إلى تآكل سيادة شخصية الكونجرس (مجلس الثـعب)التى أدت إلى تدمير المجتمع المدنى لعدم لقدرتها على المسائله القانونيه

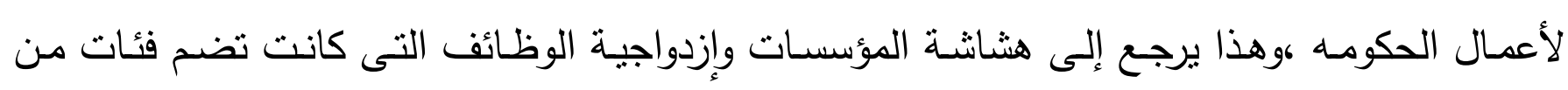

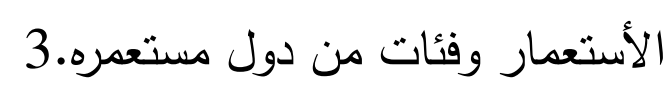
فى عام 1968 نولى سياكا ستيفنز الحكم فى سيراليون إذ تميز حكم ستنفنز فى البداية بالبلطجه في دونى العمليه السياسيه وبحلول عام 1971 تم تحويل الحكومه إلى حكومة إئتلاف وطنى ومنها إلى حكومة

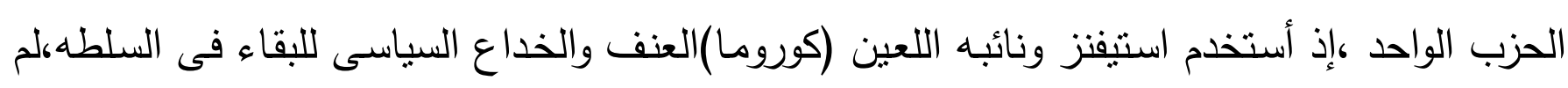

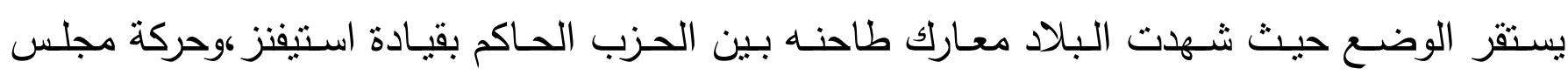
الشعب الكلى (APC)وعلى خلفية هذه الحرب بدأت الحكومه فى إعلان حالة الطوارئ وقامت الثرطه والجيش بعمليات مشتركه للقبض على المعارضه ،وعلى زعماء القبائل فى المحافظات الجنوبيه والثرقيه وتصفية المعارضين جسديا بالقتل ولم يقتصر الأمر إلى هذا الحد بل إمتدد إلى النهب والسلب وتلب وتدمير

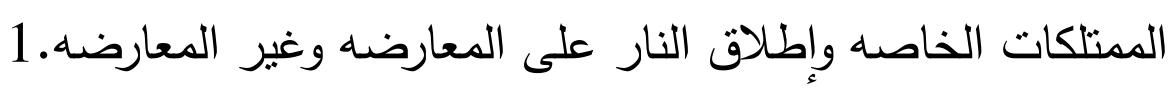

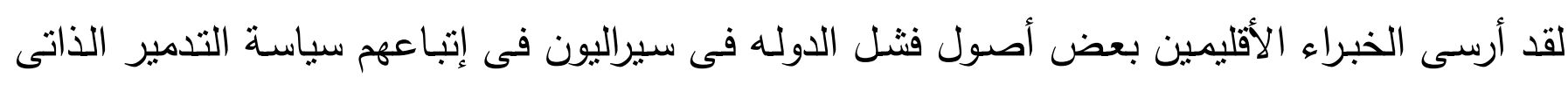
،والتى انتهجتها حكومة سياكا استيفنز منذ عام (1968 1985)وكانت هذه الأجراءات هى التى عجلت من منافسته مع خليفته المختار جوزيف موموه الذى قاد البلاد من عام (1985-1992) وهو نقابى (لفي

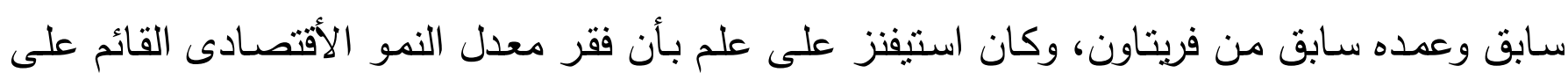


الحديد،والطعام وانتاج الكاكاو توسع بمعدل مقبول وصل لنسبة 4\%من بين عامى (1965 1973)

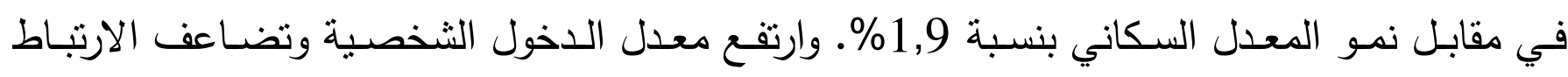

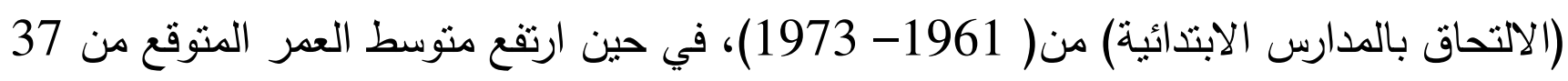

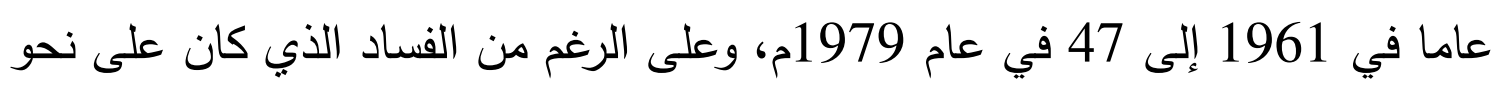
متزايد إلا أن المؤسسات العامة حققت هذا التحس.1

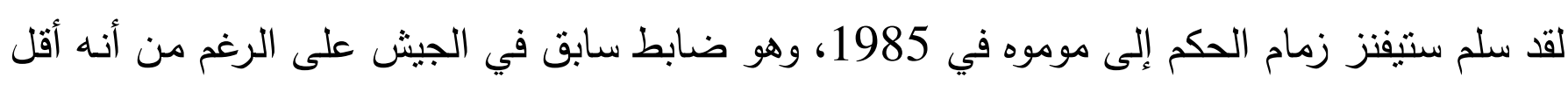



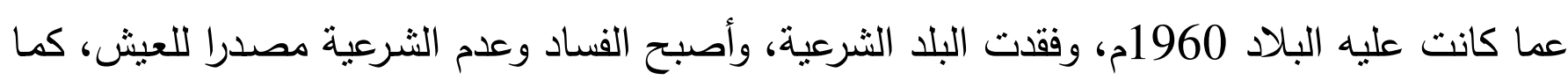

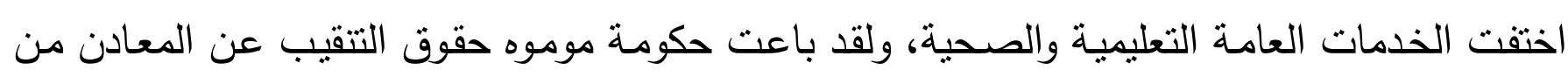

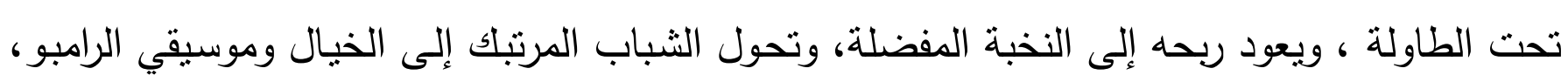

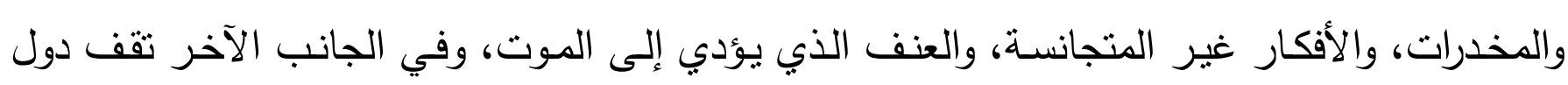

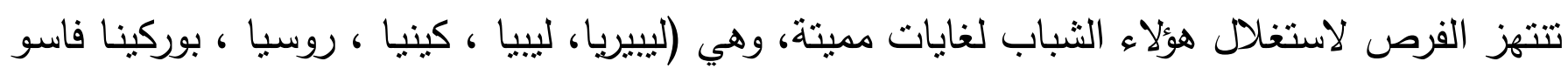
، لبنان، أفغانستان). أنثار بول ريتثارد أن كوادر الجبهة الثورية المتحدة (ruf)كانت مستوحاة من فكرة وجود الطريق الثالث

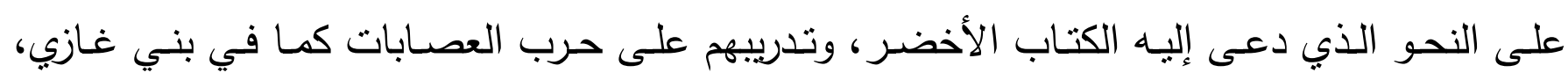

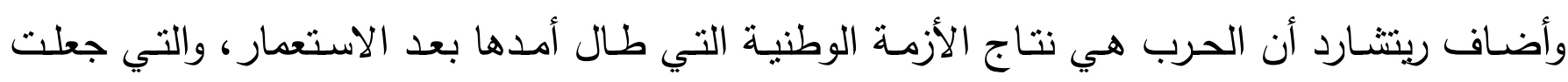

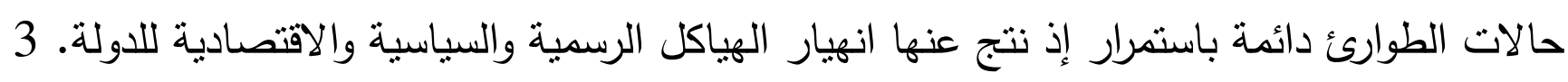

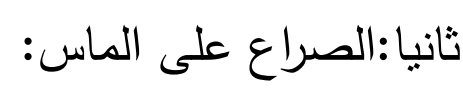

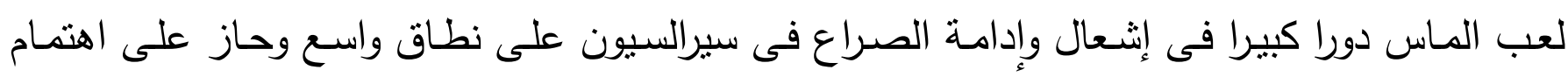

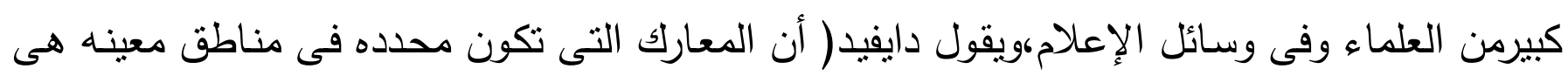

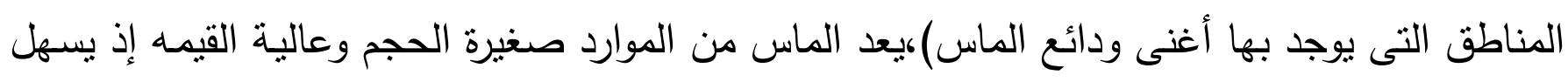

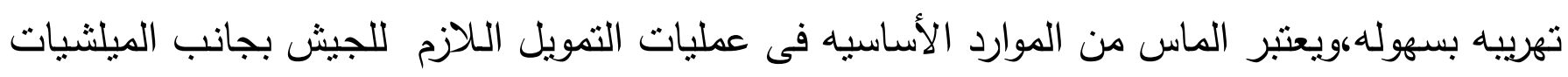

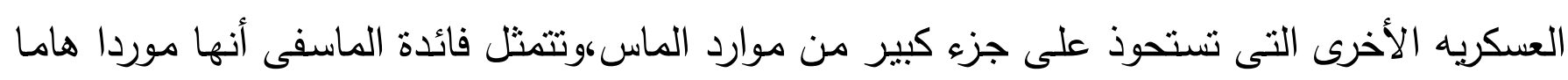

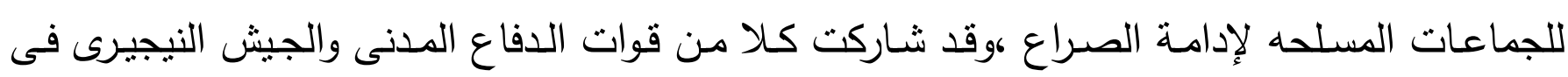
عمليات تهريب الماس خلال الحرب الأهليه في سيراليون.1 الداعن 
أدت الصراعات وأعمال العنف فى سيراليون إلى إنثاء مؤسسات محليه جديدهروالمجتمعات المحلية فى جميع أنحاء البلاد نظمت قوات دفاع مدنى مثل الجبهة الثوريـة المتحدة, وجيش تحريرالسودان وكانت قوات الدفاع المدنى مرتبطة بالمجتمعات التقليدية وكانت أكبر قوة دفاع هى الكاماجور ،ومندس وماريان

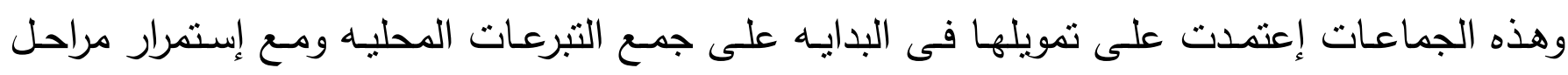

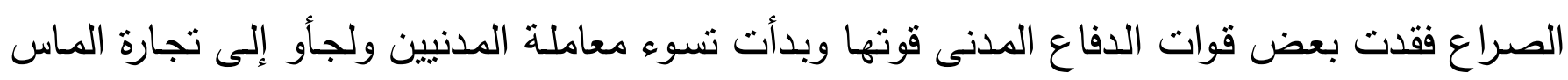
ومن هنا اتجهت الوطنيه إلى الطهع والإستغلال لموارد البيئه وأهمها المساس الذى يعد اهم مصـادر


لقد إفترض الخبراء أن إقتصاد الماس فى سيراليون ذهب للأسوء إذ بلغت صادراته 70مليون دولار فى رئ

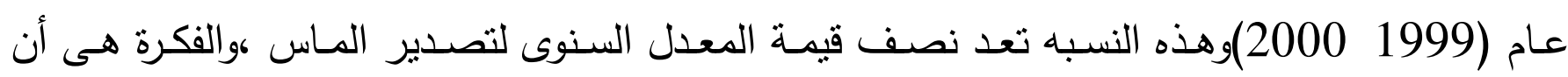
سيراليون دولة لايها ثروة كبيرة من الماس الخام الغير معلن عنه,وهذا يمثل ثروة كبيرة للسياسيين الذين


من 20إلى 50 مليون دولار من قيمة الماس إذ تستخدم هذه الأموال فى التمويل لإدامة الصراع.1.

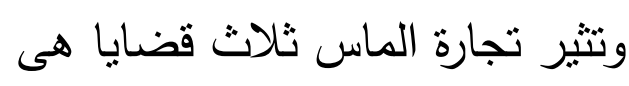
-1 هو حجم هذه التجارة وحجم الأموال المخصصـه للمتمردين (تقدر قيمـة دخل المـاس سنويا بـ300

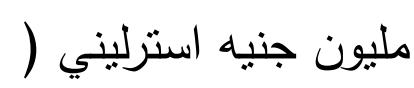
-2نقص المعلومات الحقيقيه عن المناجم وعن حجم تجارة الماس الفعلى في سيراليون

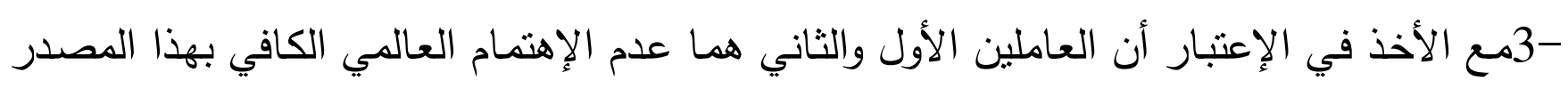
الهام لتمويل المتمردين، وكانت الحكومات السابقه في سيراليون تقوم ببيع كميات كبيرة من الماس الي الي الي الي

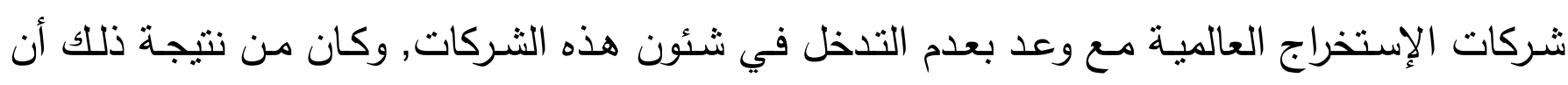
اصبحت هذه الثركات تتحكم في مناطق إستخراج الماس عن طريق تملكها لثبكة من وسائل النقل فئل

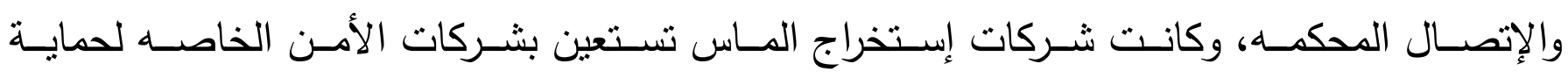

مصالحها.2.

المطلب الثانى:التعدديه الأثتيه : بدأت الحرب الأهليه فى سيراليون فى 1991 مع دخول قوات الجبهه الثوريه المتحده بقيادة فودى سنكوح الى اراضى سيراليون ،وهناك بعض الخلافات ما إذا كانت هذه الحرب تعتبر حربا إثثيه او غير إثثيه . 
فالعديد من المعارضيين ينظرون إلى هذه الحرب على انها حربا إثتيه ،لإن فودى سنكوح ينتمى إلى

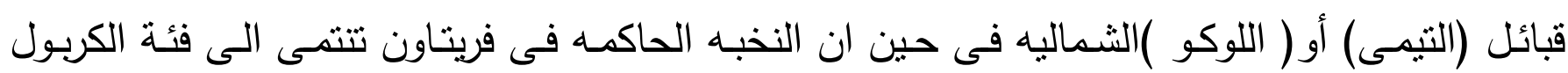
(العبيد المحررين من الأمريكتين)والحقيقه ان البعد الأثتى لم يكن واضحا فهه الحرب ،فالجبهه الثوريه


إعتمدت القاعده البشريه للجبهه على إستقطاب الثباب المحبط والثائر ،اعتمدت على الدعم والتدريب الليبيى ،بالإضافه اللى ان كثير من هؤلاء الثباب كان متأثرا بأفكار الزعيم الليبيى معدر القذافى عن

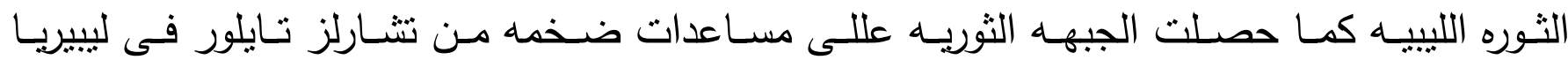
المجاوره.

في فترت حكم موموه بعد فوزه بالرئاسـه مرة أخرى خسر شعبيه كبيره واصبح منبوذ من أكثر الجماعات العرقيه ذات الأغلبيه فى البلاد إذ يعيش فى شمال البلاد وفى الوسط وفى الجنوب جماعات عرقيه ذات نفوذ يمثلون بمفردهم 60\%من سكان سيراليون،وصلت غطرسـة موموه ذروتها عندما نادى بما يعرف بهـ ب(النقابه العرقيه )واستطاع جمع رعاياه ونتكيل وحدات عرقيه اصبحت فيما بعد عصـابات عنصريه

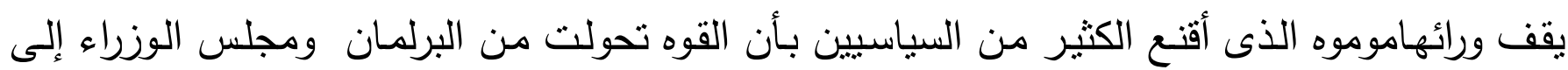
العنصريه وكانت

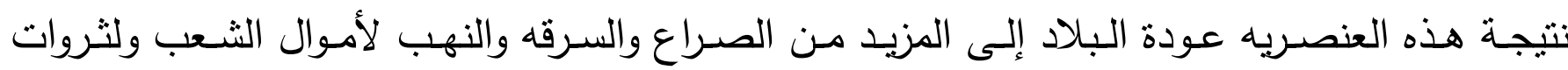
2. البلاد مع تزايد حالة عدم الأنضباط فى صفوف الجيش جعلت الحكومه تعتمد على جماعة الكاماجورى المسلحه التى تتصف بالعرقيه خاصة بعد رحيل (EO)وفنثل الأمم المتحده فى إرسال قوات حفظ السلام للمراقبه على إتقاقية حفظ السلام ،ومع تزايد إعتماد الحكومـه على الكاماجورى فى الحفاظ على الأمسن داخـل صـفوف الجيش إنعكس ذلـك على زيـادة الصــراع بـين القـوتين إذ أن مجموعـة الكاماجورى ترى ان الجيش غير قادر على حماية البلاد وغير موثوق بـه ومليئ بالفساد ،وعلى الجانب


تسعى للطعن فى الجيش بكل أسـاليب العنف وفى مارس 1996 أمرت الحكومه الكاماجورى والجيش مهاجمة المتمردين الذين يهاجمون المدينه،ونظر الجيش إلى هذا الأمر على أنه دور للحفاظ على أمن

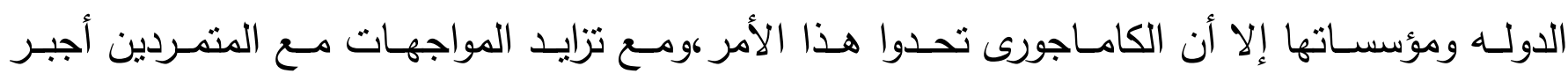


الكاماجورى على مواجهة الجمعيات المدنيه الواقعه فى الثمال، وارتفعت مكانة الكاماجورى التى كانت تعد شبه جيش وطنى مكون من الصياديين العرقيين.1.

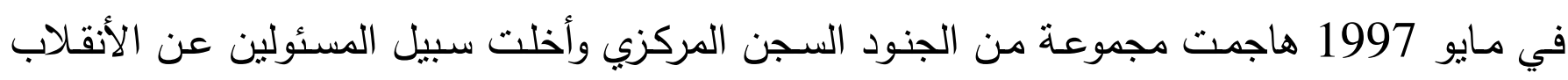
وكذلك أخلت سبيل حوالي 600 سجين, وأطاح الأنقلاب العسكري الذي قام بـه مجموعة من الصغار الضباط بالرئيس "كابـا" الذي فر الي غينيا , وتم تتصيب الميجور "جوني بول كورومـا" (الذي اطلق

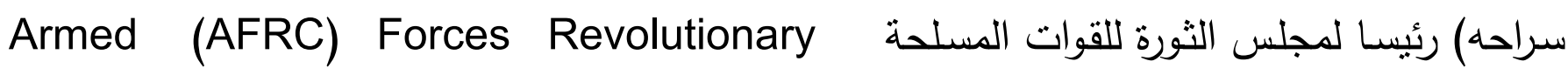
Council الرئيس كابا بإثارة النعرات القبلية بين الثعب، ومنح الأمنيازات لوحدة الدفاع المدني(الكامجور ). المبحث الثاني

$$
\text { آثار ونتائج الحرب الأهلية }
$$

بدأت الحرب بين الحكومة والمتمردين في مارس 1991 بقيام الجبهة الثورية المتحدة بمهاجمة الأجزاء

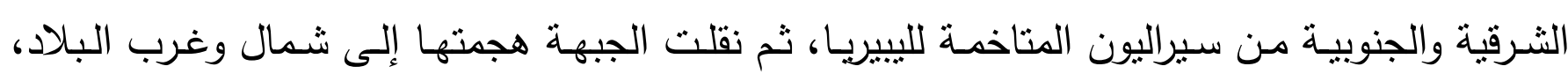
وبنهاية عام 1995م انتشرت الحرب في كل أنحاء سيراليون تاركة خسائر فادحة في النواحي الإنسانية

$$
\text { والاقتصادية والاجتماعية. }
$$

المطلب الأول: الآثار الاجتماعية : والأماعة

أسفرت سنوات الحرب الأهليـة عن 176ألف قتيل فضـلا عن تشـريد 2,1 مليون من إجمالي سكان سيراليون الذين قدر عددهم ب4,47 مليون نسمة قبل الحرب، واتصفت هذه الحرب بالمجازر الحقيقية التي استهدفت المدنيين خاصة، والنساء والأطفال الذيؤن كانوا هدفا للعنف وسوء المعاملة. أولا:ظاهرة تجنيد الأطفال:

تم أسر الأطفال في سن التاسـعة بواسطة الجبهة الثوريـة المتحدة، وبعد فترة من التنشئة الاجتماعيـة القائمة على العنف يتولون القيام بواجباتهم من المهام العسكرية، وهذه الفترة من التلقين تكون بشعة جدا، التها،

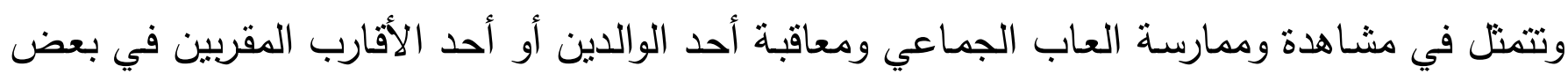

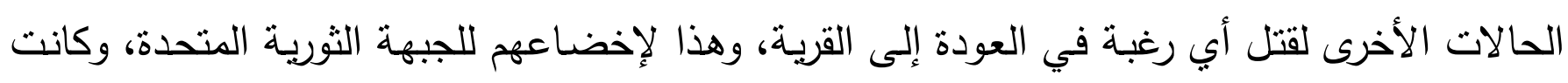

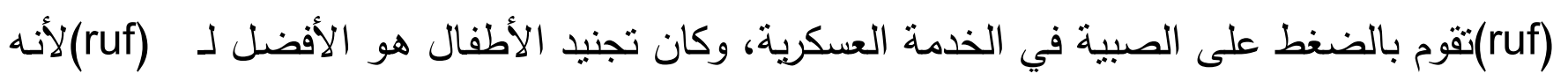

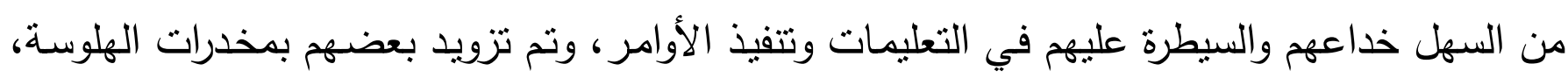
وكان عمرهم وحجمه يجعلهم مثاليين لجمع المعلومات الاستخبارية وكجواسيس في المناصب الحكومية 
نظرا لأنها تميل إلى قليل من جذب الإنتباه وكانوا يجبرون على الإختلاط بالحشود،ومن ثم بلقون بالقنابل اليدويه على جنود الحكومه.

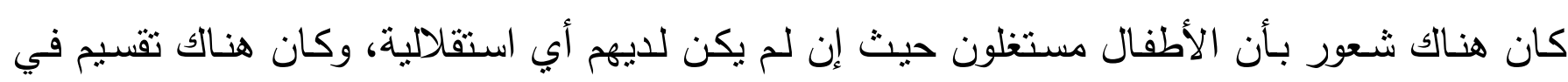


وكمحاربين في الجبهة الثورية المتحدة، وأيضا اضطرت الفتيات إلى الزواج من الجنود إذ أنشارت (لجنة

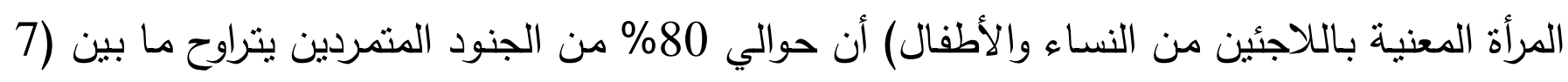

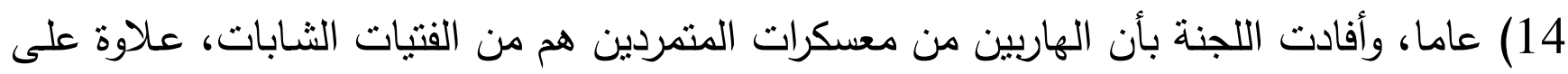
ذلك فإن حوالي 60\% من ألف محاربتم فحصهم من قبل وحدة نزع السـلاح والتسليح وإعادة التوطين التي أقامها كابـا قبل انقلاب مايو 1997، ولقد شهدت الفترة ما بين (1992 - 1996) صراعا حادا بين الحكومة والجبهة الثورية المتحدة، وتم تجنيد حوالي 4500 طفل، وفي حين عدم اثتراك الأطفال

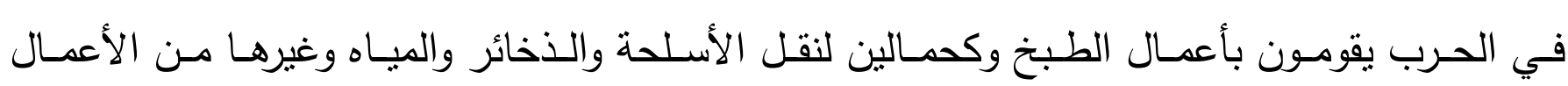
2. 2. (1)

وأمـا الأطفال فإن الحرب لم تتتـه عندما انتهت الحرب حيث تخضـع الفتبـات لاغتصـاب والإعتداء الجنسي والهجوم، ولقد أصيب آلاف منهم بصدمات نفسية شديدة، وكانوا يستخدمون في تجارب الجنس

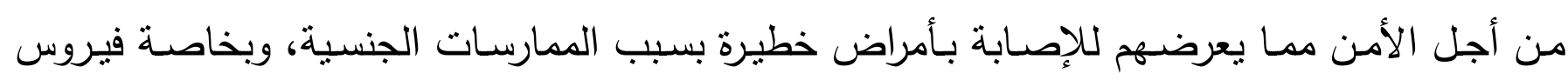

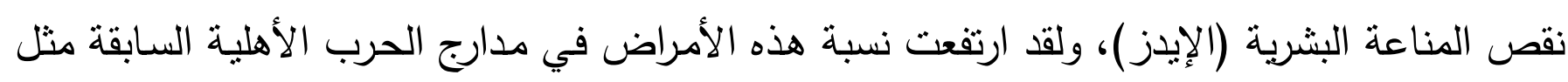

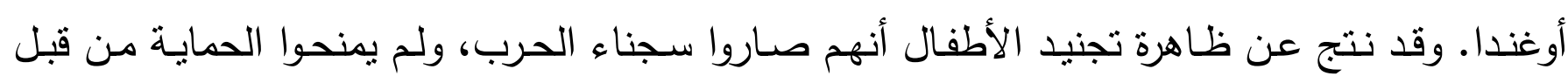
اتفاقية جنيف. وتقول لجان المرأة أن حوالي عشرة آلاف طفل ماتوا في الحروب الأهلية من بين 1,8 مليون نسمة، وأن 20\% من سكان سيراليون شردوا، وأكثرهم من الأطفال.1

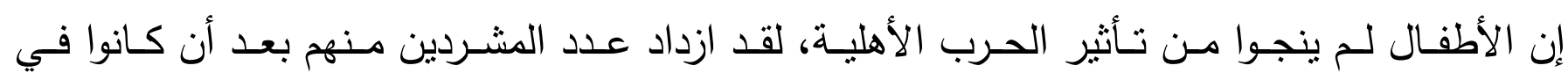
سـنة1994 ألفين صـاروا ثلاتثة آلاف في سـنة 1995، هذا فضـلا عن ألفي طفل يعيشـون مـع أسـر غريبـة، وتعـرض كثيـر مـن الأطفـال للعنف والإسـتخدام الجنسـي وتعـاطي المخدرات، وطبقـا لتقريـر اليونيسيف فإنها يوجد حوالي 400 ألف فرد دون سن 18 عامـا اضطروا إلى القتال في جميع أنحاء

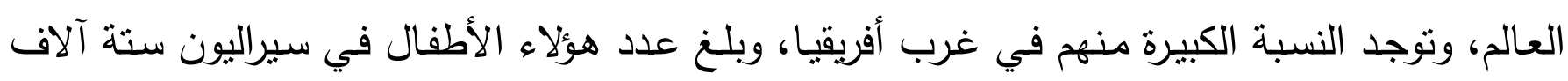

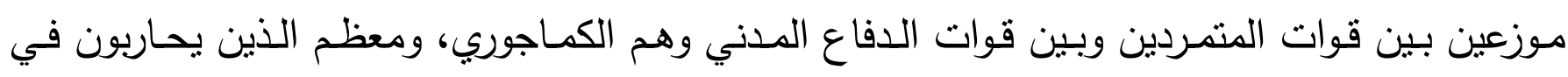
جانب قوات المتمردين تم خطفهم وكانوا يزودون بالكوكايين والمارجوانا لنزع الخوف منهم أنثاء القتال.2 
ثانيا: الحرب والمرأه فى سيراليون : وضعت الحرب الأهلية ضغوطا كثيرة على العلاقات الاجتماعية، وخصوصا على العلاقة بالمرأة التي

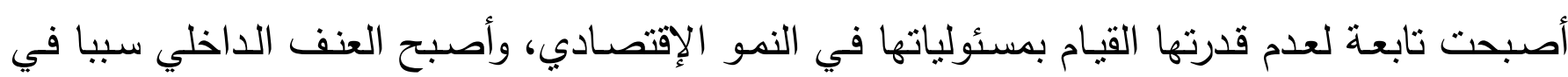

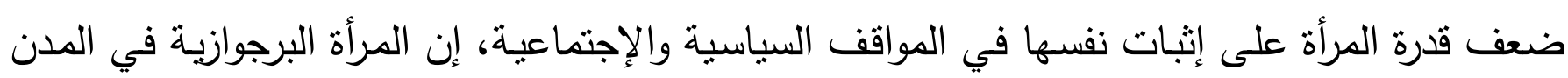
الصغيرة ستكون لها فرصة أفضل في الهروب من العنف والإستغله الجنسي، وأما بالنسبة للمرأة الريفية


الأطراف، ومن هنا يمكننا القول بأن المرأة في المجتمع الإفريقي ليس لها دور في المجتمع سوى الإهانة والقسر والقسوة وتستغل استغلالا جائرا وفقا للمؤسسات الإجتماعية الإقريقية.

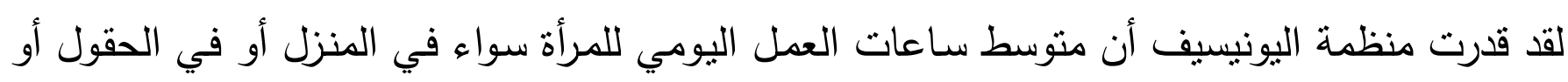
في المشي الذي يصل إلى ثمانية أميال في اليوم الواحد لجلب الخشب والغذاء والماء، وأثنار التقرير إلى في إنى

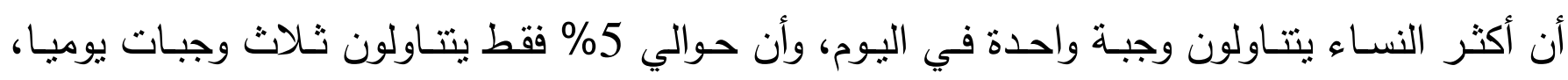

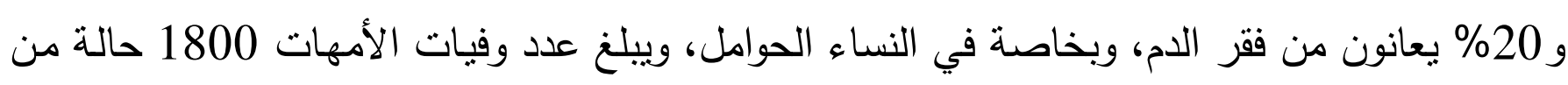
100 ألف حالة، وهذا نتيجة لسوء التغذية وفقر الدم وانتقال العدوى.3 لقد خلفت الحرب الأهلية نساء ولهاء عاجزات مشوهات، وأخر مهزومات نفسيا وعقليا، وتعرضت بعضهن للموت بسبب الألغام المدفونة تحت

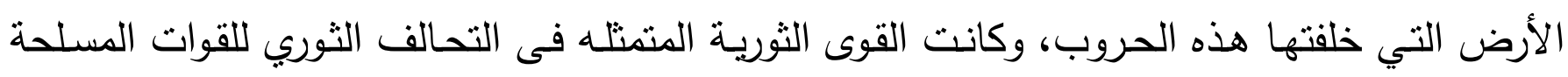

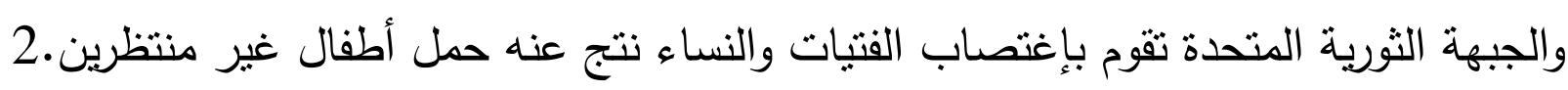
المطلب الثاني: الآثار الإقتصادية: لقد أوضحت تقارير الوكالات التابعة للأمم المتحدة استمرار تردي الأوضاع الإقتصادية في سيراليون.

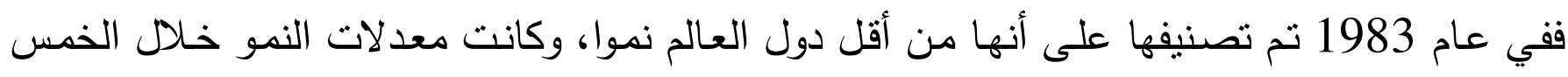

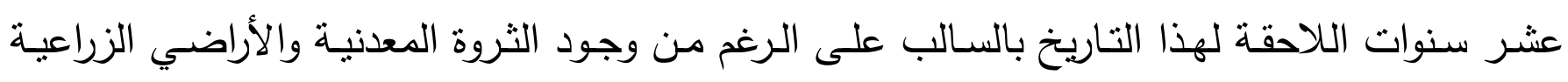
الخصبة التي لم تستطع الحكومات المتعاقبة على سيراليون استغلالها لتحسين مستوى معيثة السكان.

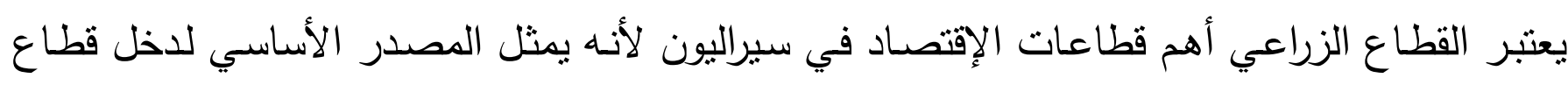




الخارجية، وعلى الرغم من أن قطاع الثروة الحيوانية والمعدنية يساهم فقط بنسبة 2\% من الناتج القومي 


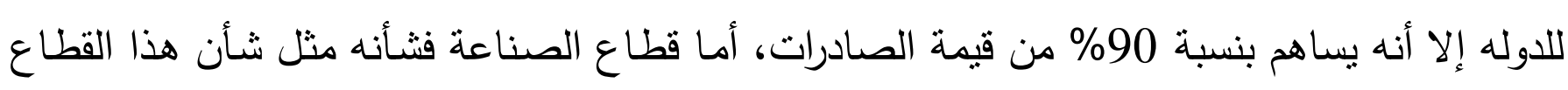

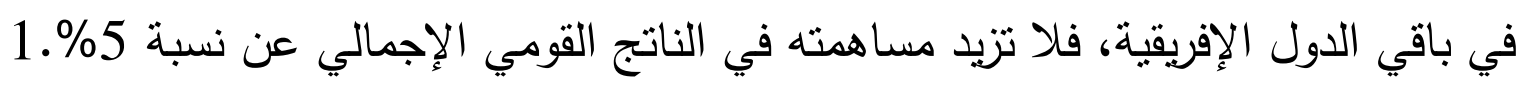
أولا: الإقتصادالرسمى للاوله : سيطرت بريطانيا على إقتصاد سيراليون سيطرة نامة، وكان لسياستها الإستعمارية دورا في تأخر البلاد



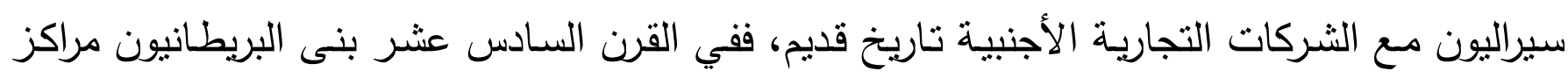

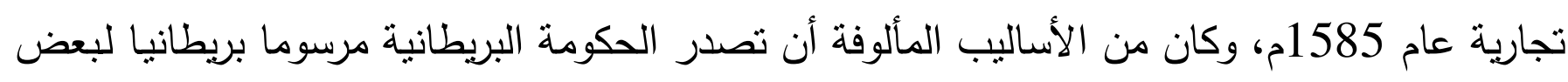



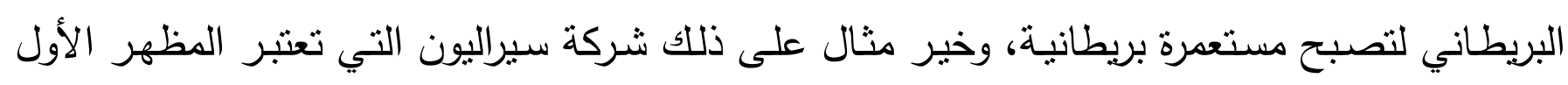

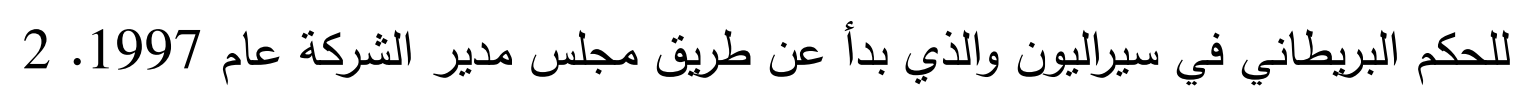

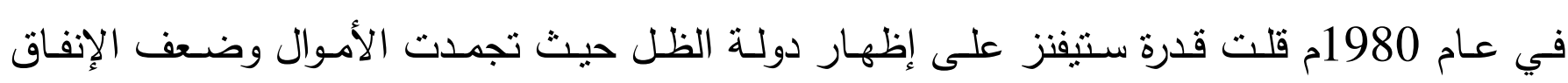

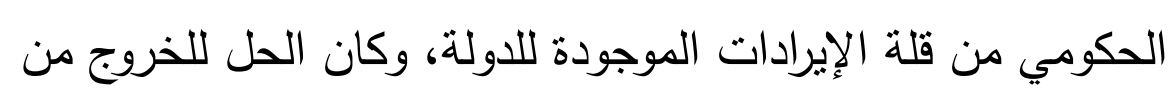

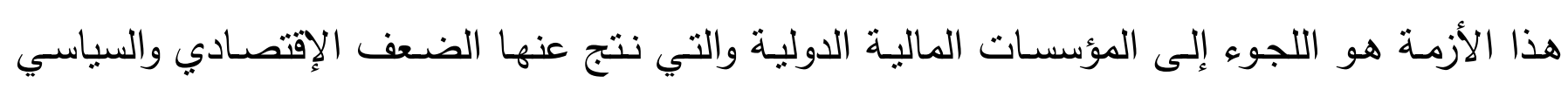



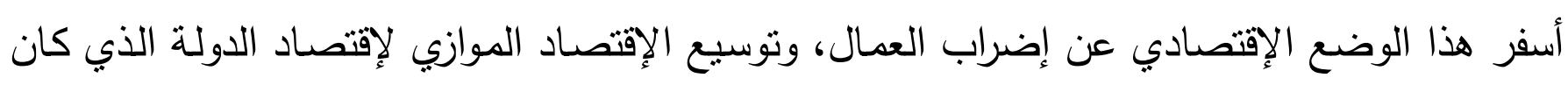

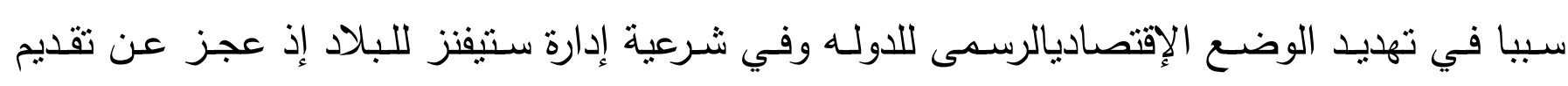

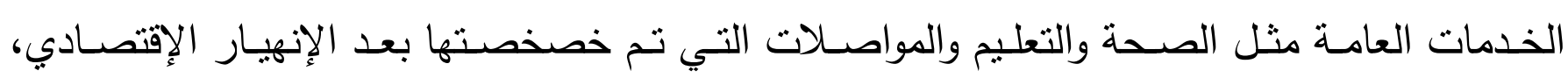

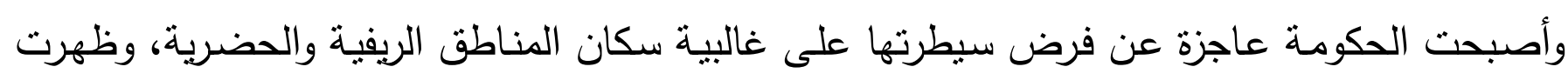

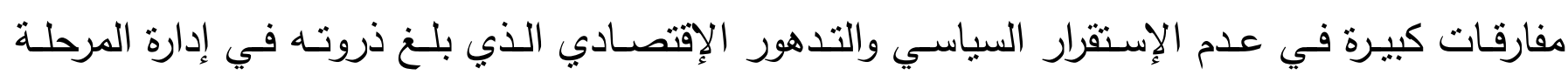

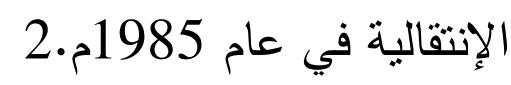
قامت مجموعة (APC)الحزب الواحد بعمليات تدميرية بسبب ما يعرف بمشروع (الثعب الكلي) ليتم

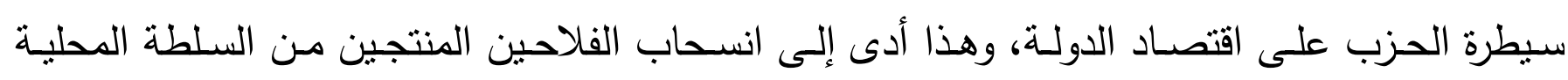



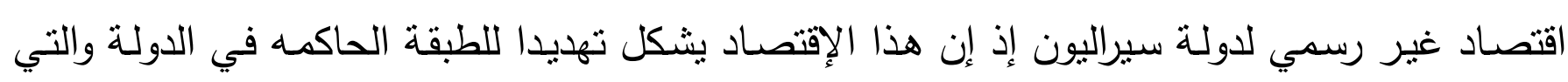

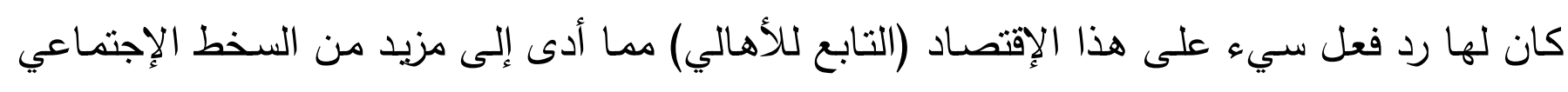

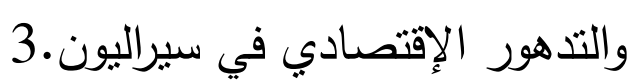


فـى منتصف عـام 1991م اتخذت الدولـة منعطفا نحـو الأسـوأ وانخفض الإنتاج الزراعى الى أدنى

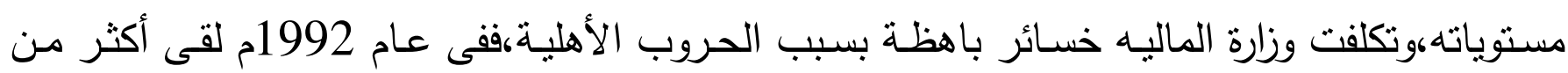
عشرة آلآف مصدرعهم وتشـرد حوالى 300ألف هو 200ألف أصبحوا من اللآجئين فى معسكرات غينيا وحوصر حوالى 400ألف بسبب أعمال العنف والحروب.1 كان هناك حاله من الرفض التام لسياسـة الحكومـة وتزامن هذا الرفض مـع إضـراب المؤسسـات الماليه

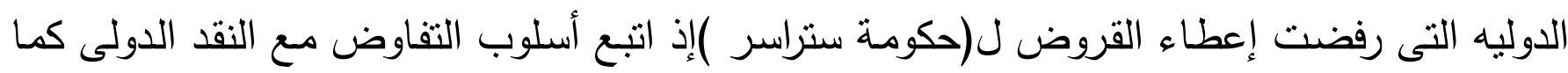

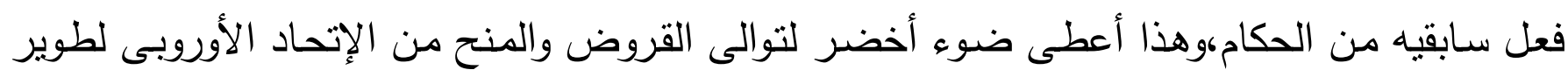

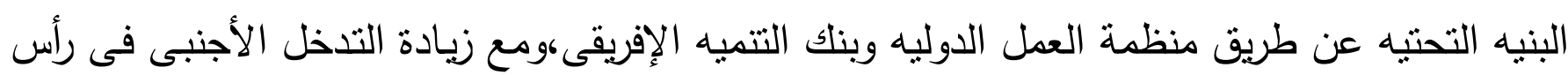
المال أدى إلى إرتفاع معدل البطاله الذى وصل إلى 30ألف عاطل عن العمل.2

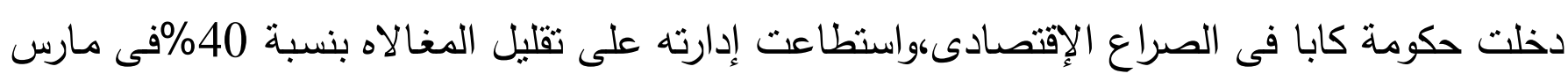
1996م إلى 6\%فى وقت الإنقلابات,وارتفع معدل نمو الناتج المحلى الإجمالى من إلى 5,6\%عام 1996 م إلى10\%,وقد عمل كابـا على جذب 750 مليون دولار من الماليـه الخارجيـه لتطوير برنـامج التتميـه

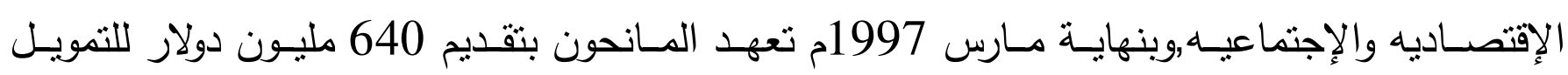

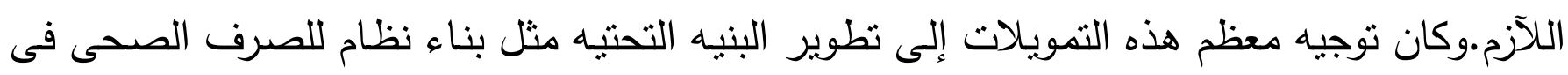

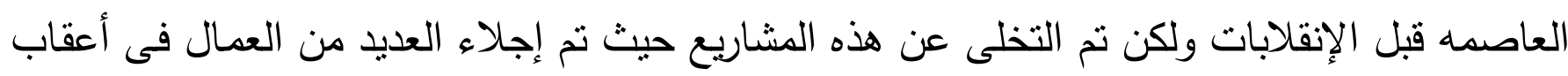

3. الإنقلاب

ثانيا:إستتزاف الموارد الطبيعيه: لعبت الموارد الطبيعيه دورا واضـحا في تاريخ الصـراعات المسلحه وتحول الصـراع من المنافسـه على الحيوانات البريه إلى الرأس ماليه التجاريه والحروب الإستعماريه بدافع المعادن الثمينه والموارد الطبيعيه أو تمويل انشطة العنف للعديد من المتحاربيين ,ومع الإنخفاض الحاد فى المساعدات الخارجيه للعديد

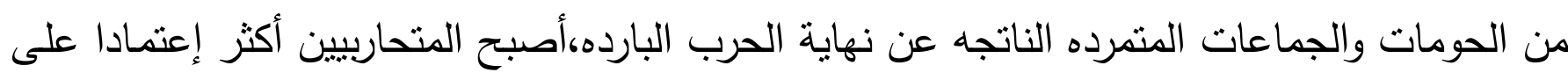

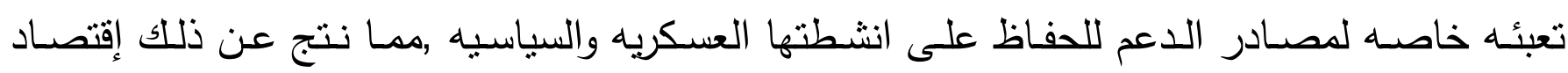
سياسـى جديد أدى إلى إنخفـاض فى معدلات التبـادل التجارى الدولى فى السـلع الأوليه والتعديلات الهيكليه مما أدى إلى إعادة ترتيب لإستراتيجيات العديد من الطبقات أو النخب الحاكمه في الجنوب نحو سياسة (ظل الدوله )مسيطريين على الإقتصاد الغير شرعى(الغير رسمى) وخصخصة الثركات.1 إنسات 
•أقر الرئيس ستراسر في بيان أدلي بـه في 6 يناير عام 1995. بأن" استمرار حرب

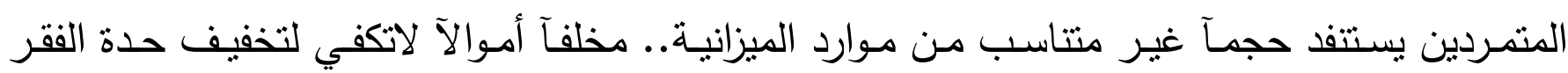


•توقف معظم برامج التتمية وارتفاع معدلات البطالة وتدني مستوي معيشة الفرد.

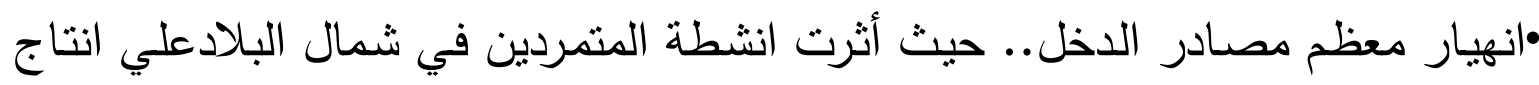

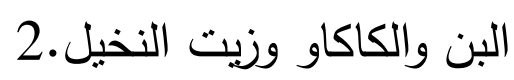
•تأثز الاقتصاد الوطني علي نحو خطير نتيجة إغلاق منجمين."سيراروتيل" الذي يوفر حوالي ثلق احتياجـات العـالم من الروتيل و "سيرومكو" للبوسيت في اعقاب هجوم المتمـردين عليهمـا،

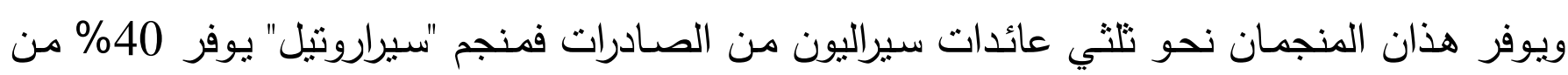


اجمالي الناتج المحلي .. ويعمل بهما مايناهز خمس القوب العاملة في القطاع الحكومي.

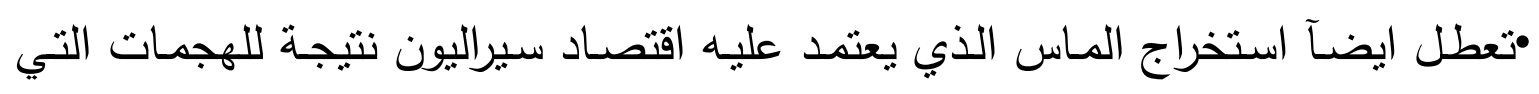

شنها المتمردين علي مدينتي كونو وكينيما. ووصف مفوضية الأمم المتحدة السامية لنسئون اللاجئين الأثر الاجتماعي للحرب الاهلية بسراليون بأنه


بالاضافة الي زيادة التدفق الجماعي الي غنيا وليبيرياكلاجئيين وتفشي وباء الكوليرا بينهم.1 المبحث الثالث

$$
\text { دور منظمات المجتمع الدولى فى سيراليون أثناء الحرب الأهلية }
$$
بعد نجاح وقف اطلاق النار قامت المملكة المتحده والولايـات المتحده الامريكيه بدفع الانتخابات في لاهي وقت مبكر ، لدعمهم لكباح وبسبب رفضهم للجبه الثوريه المتحدة لتنكيل الحكومه الانتقاليه وانهم يريدون الخروخ السريع من هذه البلد ولكن كان هناك عدم توافق كبيرعلى هذه الإنتخابات لذلك طالبت مجموعه التهات

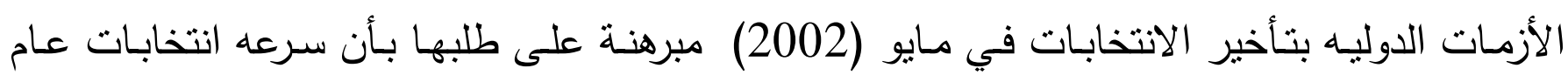

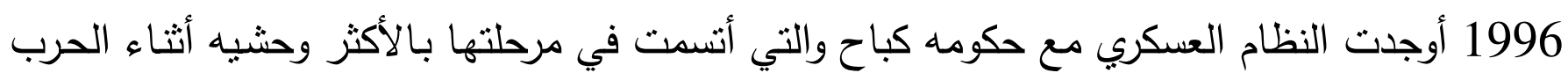

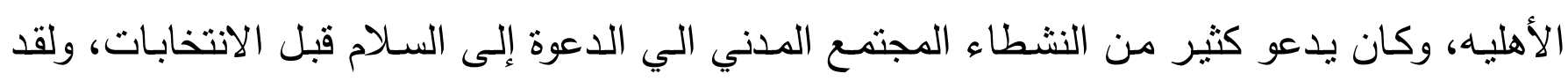

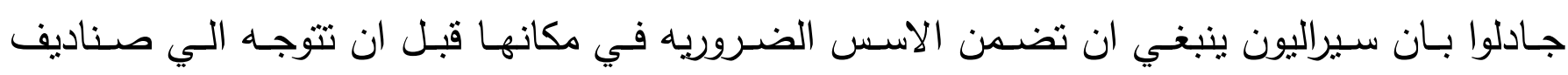


المطلب الأول:دور صندوق النقد الدولى فى سيراليون أثناء الحرب الأهلية:


الأساسية للثعب, وأضـافت وزارة التتميه الدوليه ان العشربن سنه او الثثاثين سنه الاخيره سقط نظام

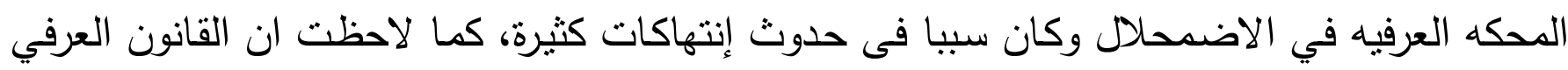
يحتوي علي انتهاكات لحقوق الانسان الأساسية مثل حالات معامله النساء، وبالنسبه لدراسه عمليات

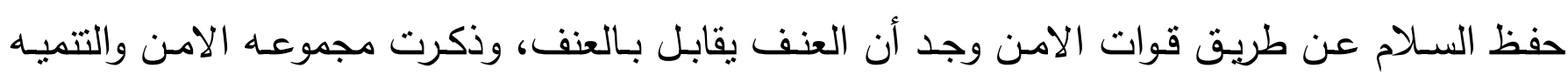

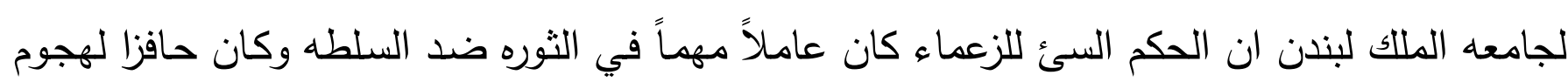

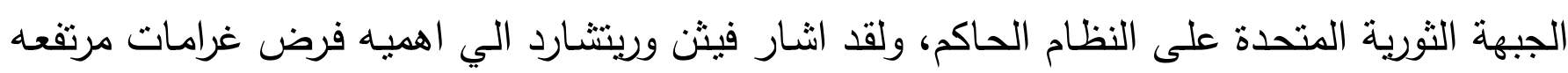

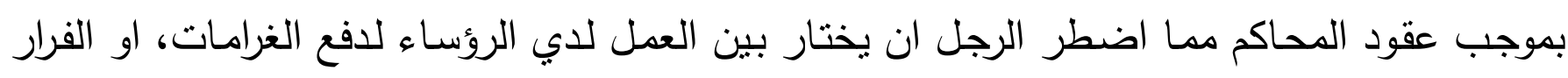

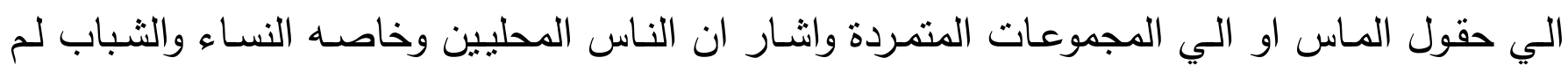
يعودوا مستعدين لهذا النوع من الاستغلال الذي عانوا منه مسبقا تحت حكم الرؤساء، ان التقيم النهائي



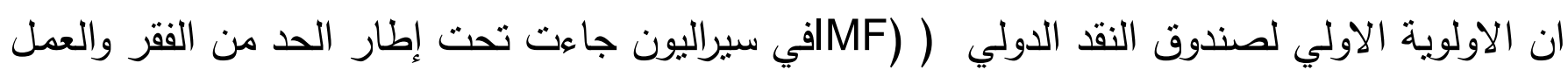



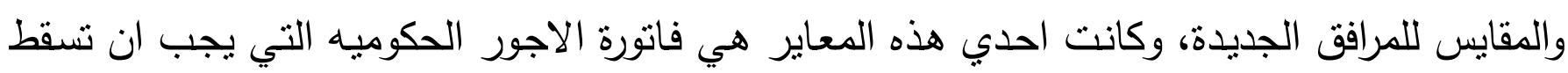

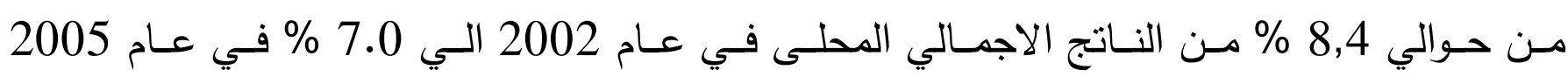
،وبالاضافه الي ذلك هناك سقف لمجموع ميزانيه الحكومه وان تلبيه هذه المعاير هي المعيار بالنسبه

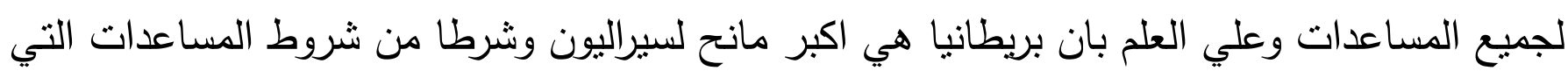



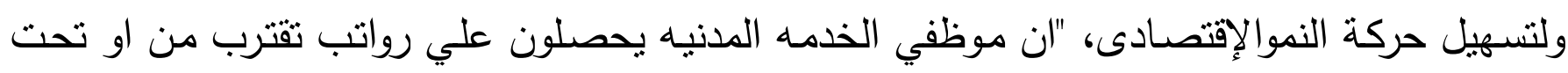

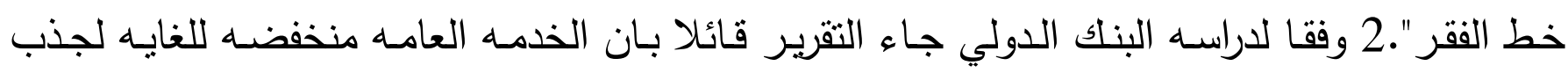
وتحفيز العاملين وهناك حاجه لتحسين اداء الموظفين، والذي يؤدي بدوره الي الاصلاح ان الن رواتب كبار

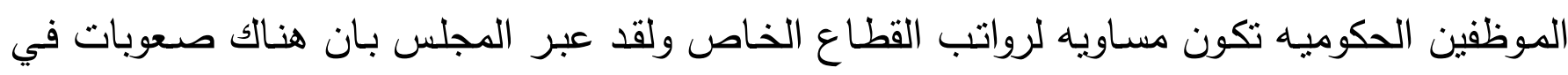
التوظيف وتحفيز الموظفين والاحتفاظ بهم بسبب انخفاض الاجور ، بالاضافه الي مستوي المهاره مما لإنا

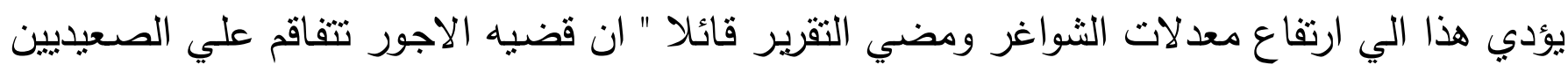

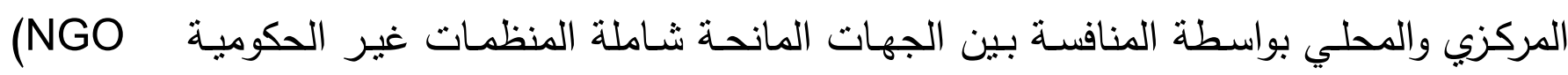


(لاولئك المؤهلين تأهيلآ جيداً إذ هم فى نقص بسبب هجرة العباقرة خـلال الحرب ،وهذا ينطبق علي

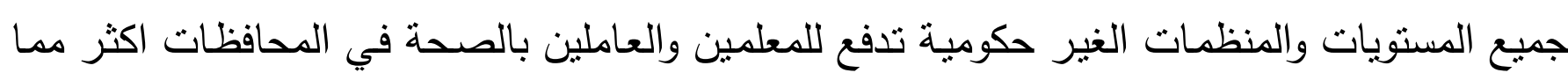
تدفع الحكومـة ولقد استأجرت بعض المنظمـات غير الحكوميـة الدوليـة بعض الامـاكن لتأهيل عمـال

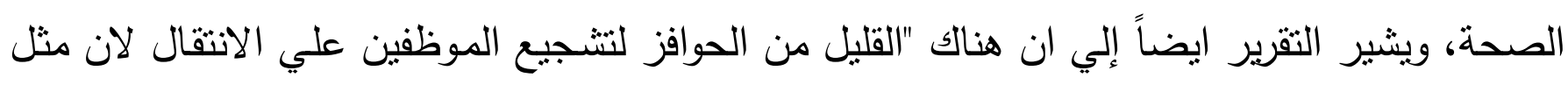
هذه المناطق النائية لا تمثل ادني جذب للعاملين او المعلمين "، ان اختتام البنك الدولي واضـح تمـام

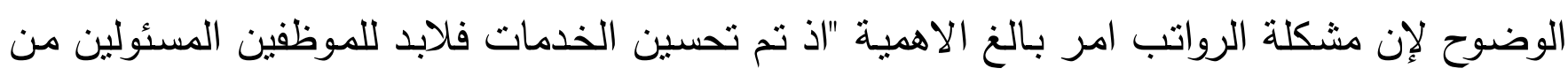
بذل مجهود اكبر مما هو عليه الان "1. ولقد اتهم العديد من المعلمين صندوق النقد الدولي بتجاهل الحرب حينما طالبت حكومـة كباح بقطع الانفاق الحكومي بواسطة قطع الارز عن الجيش وانهاء العقد مع الجنود المرتزقة في 1997 والذي ادي بدوره الي انقلابـاً عسكرياً بسبب نقص المواد الغذائية عن الجيش إذ كان صندوق النهاء النقد الدولي هو المنسبب في الضرر الهائل الذى وقع على الناس تجديد العنف مرة أخرى. 2 وبدراسـة للبنك الدولي "كسر مصيدة النزاع:بواسطة بول كولير وفريقه تم نشره في 2003 اقتبص هو هوبـ

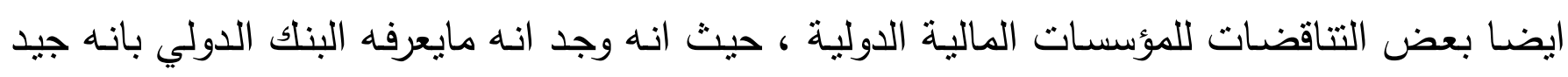

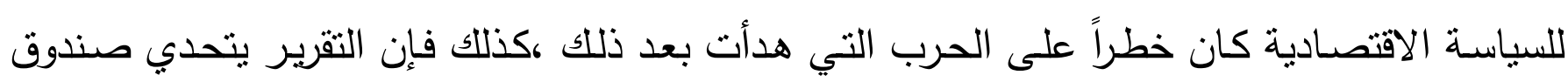
النقد الدولي إذ جاء فى هذه الدراسة ان السياسة الاجتماعية اكثر اهمية من السياسة العلمية الاقتصادية



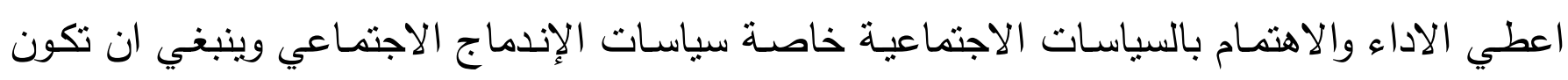



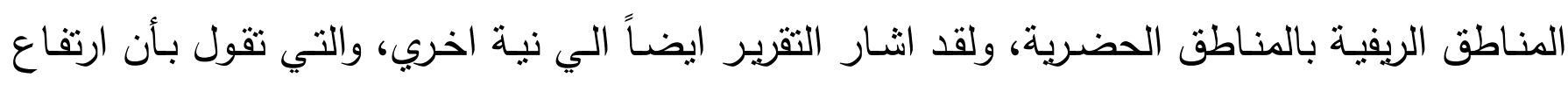

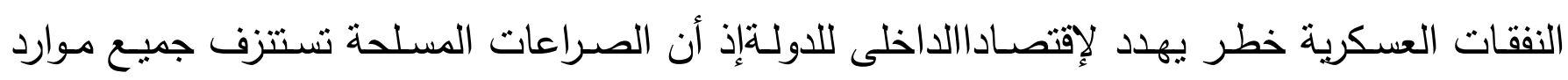
الدولة حيث تكون القاعدة العريضـة وان الانفاق الواسع له سيما في المناطق التي كانت تسبطر عليها

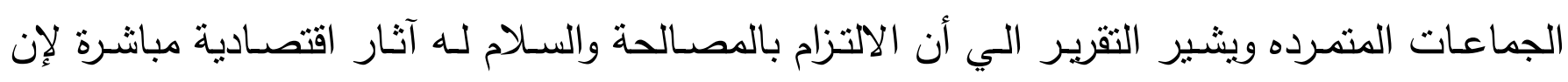
الاشارات السلمية تشجع على الإستثمار من خلال شركات القطاع الخاص والعام.1 المطلب الثانى:دور الأمم المتحدة ومجلس الأمن الدولى فى سيراليون أثناء الحرب الأهلية: كانت الحرب الاهليه في سيراليون طويله المدى متعددت الاطراف في عمليه الصراع، 
وكانت من اهم هذه الاطراف جماعـه بطلق عليها اسم الجبهـه الثوريـه المتحده ،كانت تسعي دائمـا للإطاحسه بالنظـام الحاكم منذ عـام 1968،الذى كان يحكم تحت ظل دستور الحزب الواحد وشملت

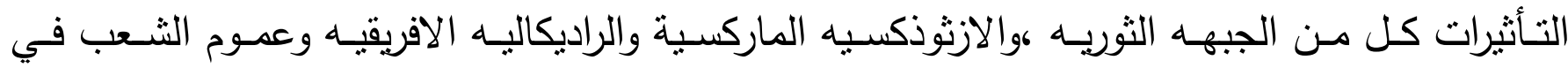
سيراليون ،وجاء ذلك نتيجه بعض الافكار الخارجيه عن دوله سيراليون المأخوذه من الكتاب الاخضر التابع الي العقيد الليبي المعمر القذافي، حيث تأثر زعيم الجبهه الثوريه فودي سانكوح بهذه الافكار وكان يتلقي تدريباته في ليبيا مـع صديقه في الحرب رينتـارد تايلور قائد حركه التمرد في ليبريا ،واستطاع سنكوح ان يكون جماعات متحده تعرف بأسم الجبهه الثثريه المتحده تقوم بحرب عصابات ضد الجيش الوطني السيراليوني منـذ عـام 1991 حتي عـام 1999، وهـي فتره الحكومـات المتعاقبـه علي حكم سيراليون بدايـة من رئاسـه جوزيف مومـوه التي كانت تهمـن علي الثـمال مـن عـام (1985 1999) ومعها المجلس العسكري الوطني الموقت ومجلس الحاكم (NIR2)التي فنثلت فى انقلاب قام به صغار الضباط فيعهد الرئيس الرئيس المنتخب احمد تيجان كابا الذي اسس حزب الثعب السيراليوني في فبراير 1996 كان سببآ في انشقاق بعض افراد الجبش وانضـماههم الي الجبـه الثوريـه المتحده للعمل ضد الجيش الحكومي وضد حزب شعب سيراليون القائم علي اساس الحزب الواحد.1 في عام 1996 نم توقيع اتفاقيه (ابيدجان)والتى تنص علي وقف الحرب ونزع السـلاح ولكن سرعان نقدت هذه الاتفاقيه من فبـل الطرافين ،واستمرت الحرب في المنـاطق الجنوبيـه والثـرقيه لمحاوله كـلا الطرافين السيطره علي هذه المناطق لتحقيق اكبر مكسب من التواجد علي الارض وأرتكبت المجازر

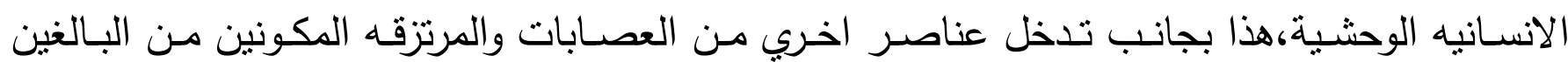
والمـاقتلين ودون السن والهاربين مـن السجون إذ كانوا يقطعون الطرق علي المسـافرين لسـلب اموالهم وقتلهم، وانتقلت العدوى من قطاع الطرق الي الجنود الغير نظامين اذ كانوا يستخدمون بعض المتمردين

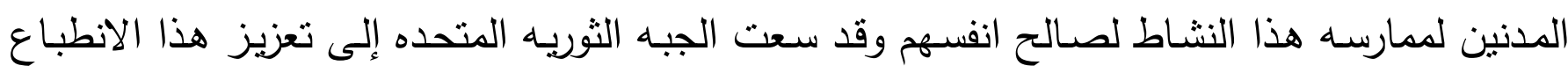
لدي الرأي العام الدولي من خلال ارتداء ملابس للجيش النظامي ويقمون بقطع الطرق علي المسافرين ويسلبون اموالهم من اجل أن يسود انطباع بان الجيش هم الذين يقومون بهذه الاعمال الجراميه.1 لعبت ليبريا دورا هما في سيراليون وهذا في منتصف عام 1991 اذ كانت وحدات الجبه الثوريه المتحده تتلقي دعما وتدريبات في ليبريا وكان مقرها (mattru)وهذه المنطقه توجد في ليبريا تقع مع حدود منطقه بو السيراليونيه اذا كانت تتصسب الكمائن لقوات الجيش السيراليوني مـ اجل الحصـول علي الاسلحه والاموال التي تمكنهم من القيام بحملتهم ضد حكومـه سيراليون قادت الجبه الثوريـه المتحده 
الحـرب مـع النظـام الحساكم لسـيراليون بمسـاعدة بعض القـوات الخاصــه التابعـه لليبريـا وبوركينافسـو

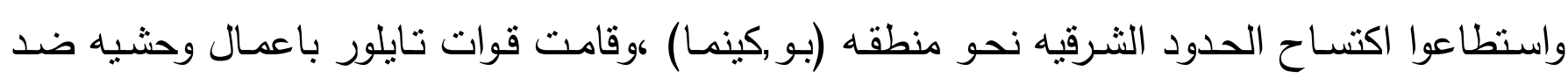

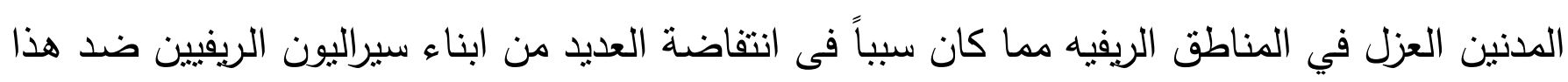

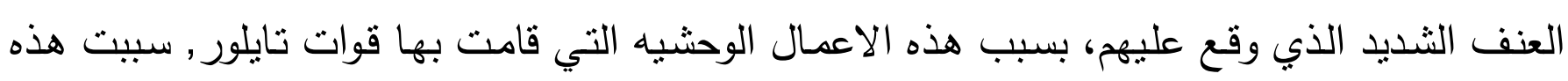
الاعمال الوحشيه فقدان شعبيه الجبه الثوريه المتحده وخسرت المبادره التي وقعت عليها وتدخلت القوات الاجنبيه لحفظ السلام تحت القياده النيجيريه وبمشاركه المجموعه الاقتصاديه لغرب افريقيا. تم نشر قوات علي طول الجسر الاستراتيجي لنهر (سبوة) في غونداما جنوب بو مكونهـ من عناصر الجيش النيجيري وفقا لأحكام معاهدات الدفاع المشترك ،وفي نفس الوقت كان هناك قوات في (دارو شرق كينما) من الجيش الغيني للدفاع عن نفس الجسر ولوقف اي تقدم من الجبه الثوريه المتحدة من

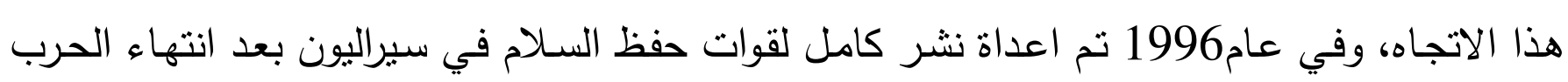
الليبيريه لضمان عمليه حفظ السلام في اعقاب اتفاقيه ابيدجان.1



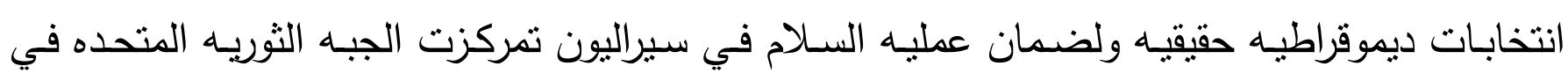

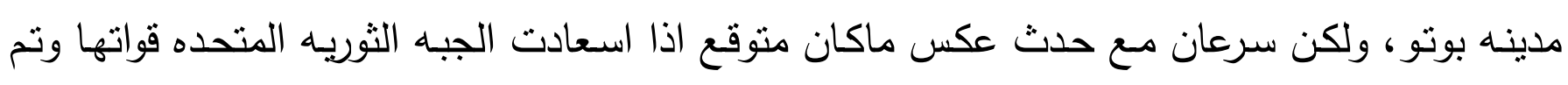
الهجوم علي مدينه فريتاون مرة اخري ،وخلفت خسائر كبيره جدا من عناصر الجيش النيجيري مما كان سببا في ان تعيد نيجيريا النظر في التزاماتها في عمليةحفظ السلام بعد ان توصلت الي تسويه جيده مـع


من نجيريا وقوات من كينيا، وزامبيا ،والاردن، والهند لاستكمال عمليات حفظ السلام فى الانسحاب ونزع

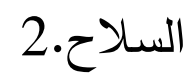
في عـام 2000 نشـرت قوات حفظ السـلام قواتهـا وفقـا لتفاقيـه لـومي اسـتكمال عمليـه نـزع السـلاح المخطوف من الوحدات الغينيه, وتم تزويد هذه القوات بقوات من الامم المتحده لتعزيز قواتها بعد ان انتشرت شائعات بان الجبه الثوريه المتحده تحاول الهجوم علي مدينة فريتاون وعلي اثر هذه الثـائعات قامت بريطانيا بنشر 1000 جندي في المدينه لحمايتها وحمايه المطار من اي اعتداءوقد قام الجيش البريطاني باشتراك في تدريب الجيش السيراليوني الجديد حتي تمكن من حمايه امن البلاد وبحلول نهايه عام 2000 وصلت اعداد قوات حفظ السـلام في سيراليون الي 17500 جندي هذا بجانب المعدات فئني التقيله والمروحيات المقاتلـه التي تسـاعد القوات في عملياته. وتتشير بعض التقارير الخاصـة بـالخبراء 
المعنيين من فبل مجلس الامن الدولي الذين تولي مهام فرض العقوبات علي ليبيريا عام 2001 ،هذا التقرير يعكس قرارات سياسيه اتخدها المجتمع الدولي ضد الجبه الثوريه المتحده لوقف مصـادر الدعم

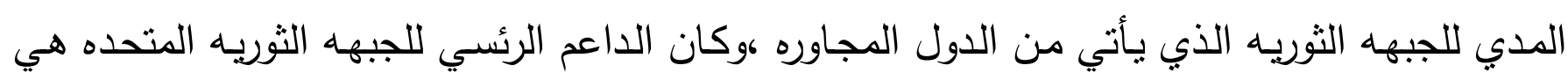
دوله ليبريا التي كانت تمدها بالسلاح والجنود مع وجود تعاون مشترك في عمليات تهريب الماس لصالح الطرفين وكان سعي مجلس الامن الدولي هو العمل علي وقف هذه الدعم الخارجى للجبهه التثرية التي

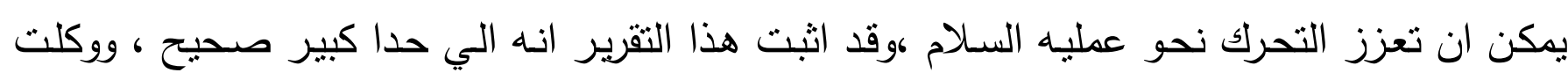

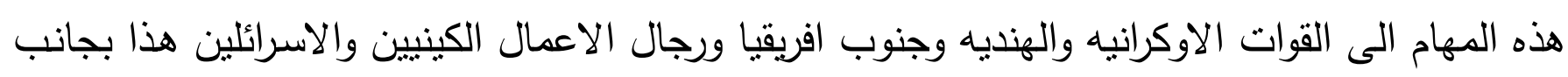
بعض الخبراء العسكرين لقطع الطرق المؤديه الي ليبيريا او الى اي قواعد اخري مثل (بويدول، الي

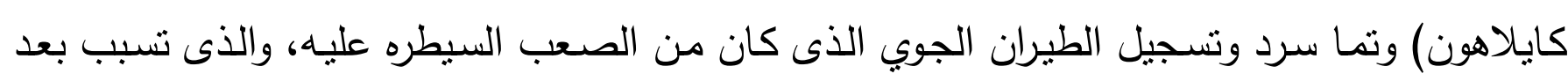
ذلك في الهجوم علي مدينه فريتاون من قبل الجبهه المتحده الثوريـه بعد وصول امدادات من ليبيريا وبوركينافاسو عن اوروبا الثرقيه رواصبحت عمليه السلام مهدده بعد توقيع اتفاقيه لومي 1999 وكان من اهم اهداف عمليات حفظ السلام هي قطع مصادر الامداد التي تأتي الي الجبهه الثوريه المتحده.

المبحث الرابع جهود التسوية للخروج من الأزمه

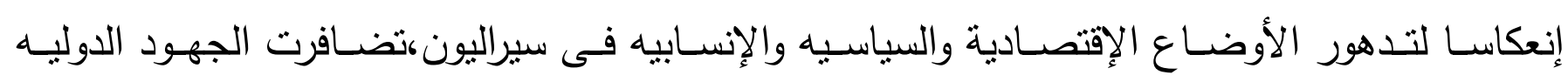
والإقليميه لوضع حد للحرب الدائره بين قوات الحكومه وقوات المتمردين،إلا أن الجهود الإقليميه كانت اكثر نجاحا فى وضع حد للصراع الدائر فى سيراليون. المطلب الأول:الجهود الإقليميه: لعب المفاوضون الإقليميون دورا أساسيا غى الجهود المبذوله فى مفاوضات السلام بين الطرفين،حيث

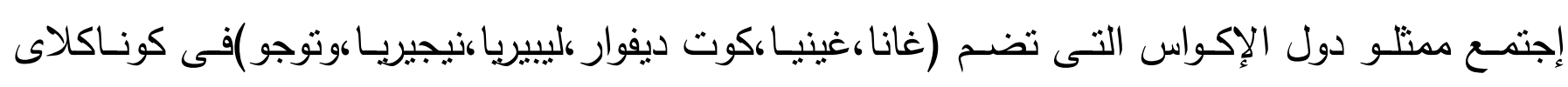

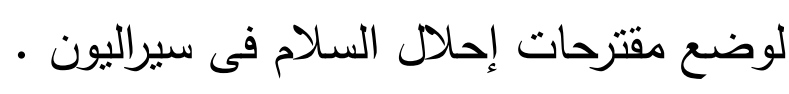
لعبت نيجيريا دورا رئيسيا وفاعلا في حل الأزمة في سيراليون حيث تعتبر القوات النيجيريه هي العمود الفقري لقوات الـ ECOMOG، وجدير بالذكر أن التواجد العسكري النيجيري ظهر في عهد الرئيس

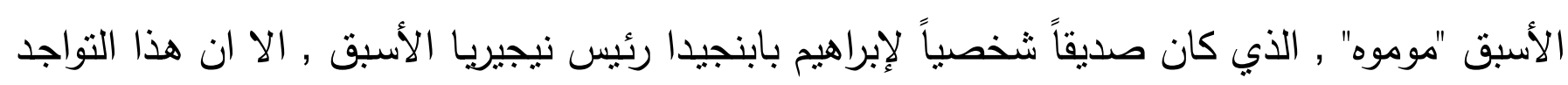

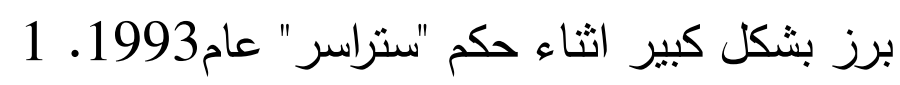


ومنذ ذلك الحين قامت القوات النيجيرية المتواجده علي آرض سبراليون بتقديم الحماية لحكام سيراليون

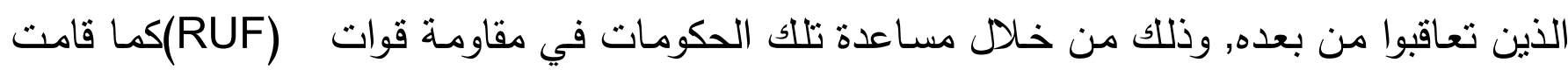
السلطات النيجيريـه بإعتقال "فوداي سنكوه" زعيم الجبهة الثوريـه المتحدة وسلمته لحكومـة الرئيس كابـا

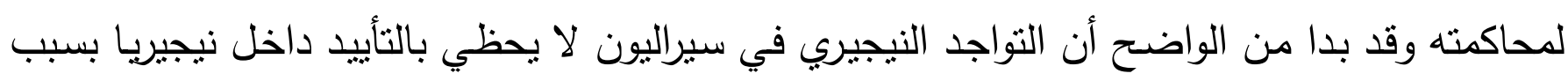

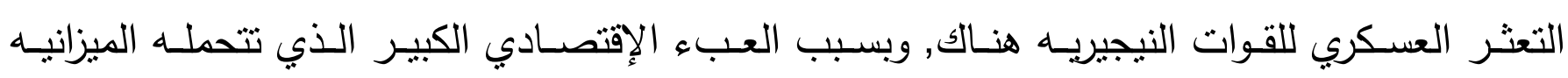

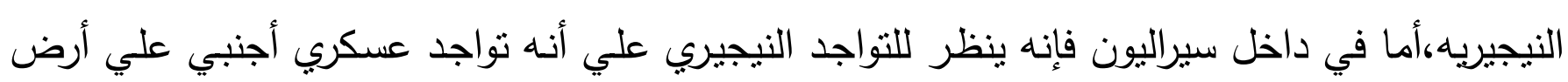

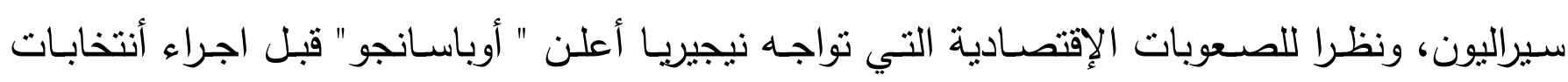
الرئاسه النيجيريه عام 1999, أعلن عن عدم رضاه عن استمرار تواجد القوات النيجيريه في سيراليون، كما صرح الحاكم العسكري في ذلك الوقت الجنزال ابو بكر بأن القوات النيجيريه ستتسحب عند من سيرالئن

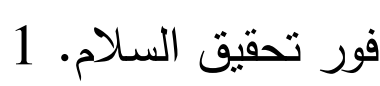
ومنذ أحداث يناير 1999م، أدرك حلفاء الحكومـة الثـرعية (بإستثناء قلـة حول الرئيس كابـا) إستحالة تحقيق نصر عسكري, لذلك رأوا ضرورة بدء الحوار مع قوات المتمردين, علي الأقل في حالة عدم وجود مفاوضات معهم , وكان الرئيس كابا واقعا تحت ضغط قوي من قبل نيجيريا وغانا وغينيا للتعجيل ببدء

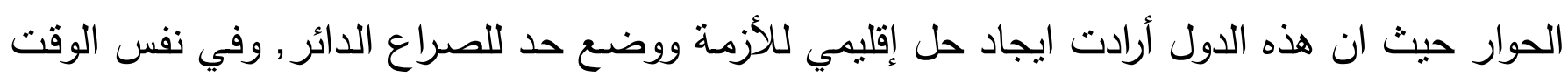

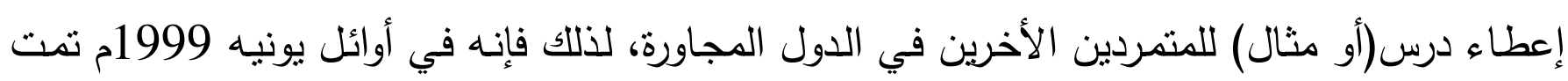

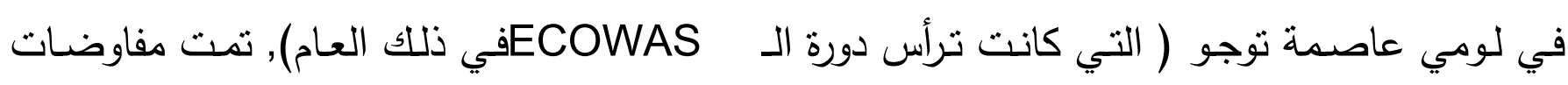

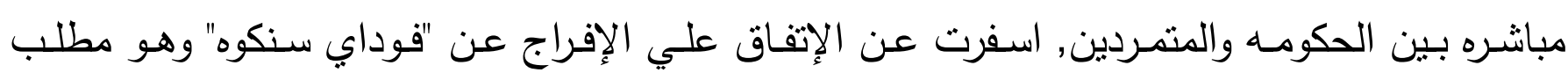
اساسي من مطالب الجبهة الثوريه المتحدقتوأسفرت الجهود المبذوله بشأن تسوية الوضـع في سيراليون عن توقيع اتقاق سلام بتأييد اقليمي ودولي كبيريين، وقد رحبت مصر بتوقيع إتفاق المصالحه الوطنيه


المصالحه الوطنيه وينهي ثماني سنوات من القتال, واثناد بدور الرئيس "إياديما" رئيس توجو في ابرام

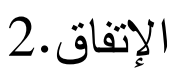

المطلب الثانى :الجهود الدوليه لتسوية الأزمه: وفيما يلي عرض لجهود كل من بريطانيا والولايات المتحدة والأمم المتحدة. أولا:بريطانيا: 
استضافت لندن الإجتماع الثالث لمجموعة الإتصال حول سيراليون في 28 يوليو 1999 م (وتضم هذه المجموعة ممثلي سيراليون والأمح المتحدة والمنظمـات الدوليه والاقليميه المانحسه مثنل الإكواس والبنك الدولي والكومنولث )بهدف حشد الدعم الدولي لتحقيق السـام والإسـتقرار في سبراليون وقد شـاركت بريطانيا العظمى بحوالى 120مليون دولار لإعـادة الإعمـار فى سيراليون والمؤسسـات الأمنيـه ونظسام العداله وفى ذروة عام 2001م كانت ميزانية قوات حفظ السلام حوالى 744مليون دولار كانت جميعها

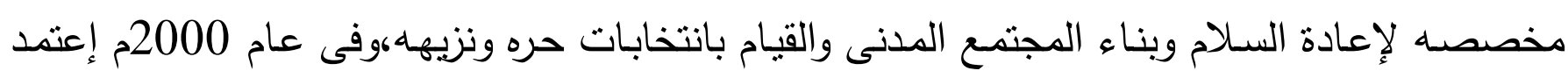

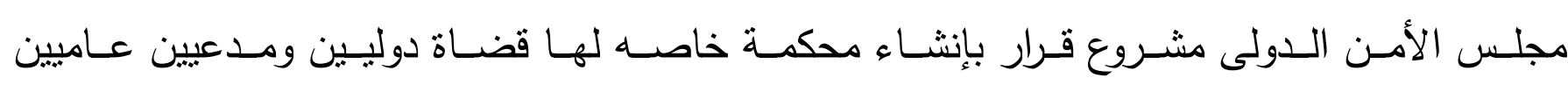
لمحاكمة|لمتمرديين المخربين ثانيا:الولايات المتحدة الأمريكية: إنطلافا من أهتمام السياسـه الأمريكيه بالقارة الأفريقيه منذ اوائل التسعينات تابع المسئولون الإمريكيون تطور الصـراع الدائر في سبراليوم باهتمـام. وقد ظل السفير الأمريسي في سبراليون علي اتصـال دائم احا بائيس كابا من مقر اقامته في غينيا. وفضـلا عن فيام الولايات المتحدة بتدريب الـ ECOMOG رعاية امت الحكومة الأمريكيه بتزويد مؤسسه


مقابل تزويد

المؤسسه لقوات ECOMOG بالإمدادات العسكرية, هذا بالإضافة الي مساعدة الولايات المتحدة لغينيا (وهي الدوله الإفريقيه الأكثر تآثز بالصراع الدائر في سيراليون) في ثناث مجالات هي هماية البيئة,

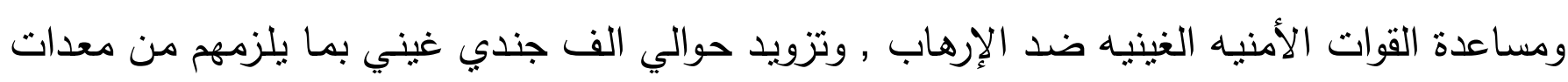

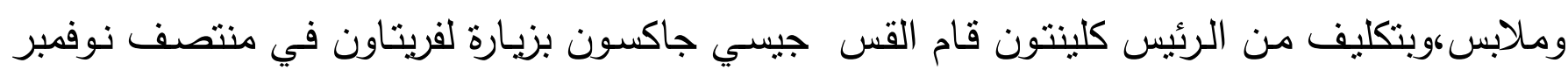
1998, وقدم له تقريرا تضمن اقتراحا بضرورة تفاوض حكومة سيراليون مع المتمردين ، وفي 19 أبريل

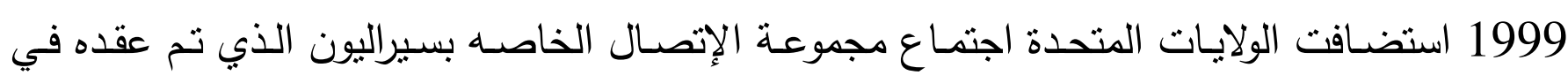
نيويورك وفي مستهل جولتها الافريقية وصلت مادلين اولبرايت وزيرة الخاريجة الأمريكية في 18 أكتوبر الإني 1998الي سيراليون وأجرت محادثات مع الرئيس احمد تيجان كابا وجوني بول كوروما وفوادي سنكوه, لمتابعة ددي الالتزام باتفاق السلام الموقع بين الجانبين في شهر يوليو , واعلنت في اثتاء زيارتها لمالي




غرب افريقيا, كما تعهدت بتقديم مساعدات أمريكية اضافية قيمتها 55 مليون دولار لاحلال السلام في سيراليون.1. ثالثا: الأمم المتحده: فى أعقاب الهجوم الوحشى على فريتاون عام 1999م قامت الولايـات المتحدة اللأمريكيه والأمم المتحدة بنشر قوات كبيره لوضع حد لهذه الحرب,وكانت هذه القوات بمثابة حمله لنزع السلاح واستطاعت توقيع معاهدة سلام فى عام 2002م بين الجهات المانحه والمنظمات الغير حكوميه , ولقد لعبت منظمة (NGO)دورا رئيسيا فى إعادة الإعمار للبنيه التحتيه وإعادة توطين النازحين داخليا وتمويل الحكومه لإجراء إنتخابات لإختيار رئيس للبلاد واختيار أعضاء البرلمان لعام 2002م.2 لإنيا

علي الرغم من أن مجلس الأمن بقضي حوالي 60\% من وقت جلساته في مناقنشة القضايا الآفريقية إلا

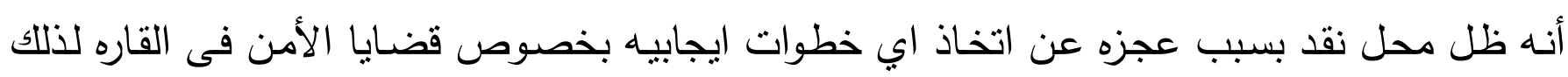


في البحث عن حل لإزمة سيراليون, ومن هذه الحلول فرض نظام الحظر طبقا للقرار رقم 132 في 8

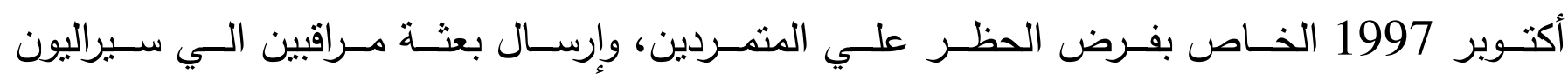
التي تتكلت في (UNOMSIL) The United Nations observer Mission in Sierra Leone 3 يونيه وامتد عملها حتي 13 يونيه 1999، إلا أنه تم تقليل عدد المراقبين بسبب هجمات المتمردين في يناير 1999، حيث تم تقليل عدد البعثة الي ثمانية افراد تم نقلهم الي كونا كري بعد ان كان عددها


الأمن علي القيام بدور فاعل في سيراليون الي عدة اسباب منها: غياب الأسباب التقليدية التي تستدعي وجود قوات حفظ السلام للأمم المتحدة مثل مراقبة وقف اطلاق


الإمكانـات ،اعتراض بعض اعضـاء مجلس الأمـن خاصـة الولايـات المتحدة الأمريكيـة علـي ارسـال

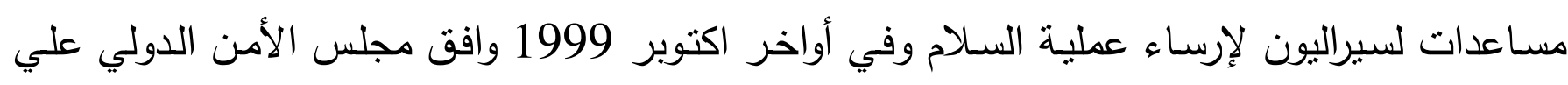
نشر قوات حفظ سلام قوامها 6 الاف فرد للمساعدة في تتفيذ اتفاق السلام. 1

خاتمه *علي الرغم من ان الصراع في سيراليون بدأ داخليا بين الجبهة الثورية المتحدة ومن بساندونها من جهة

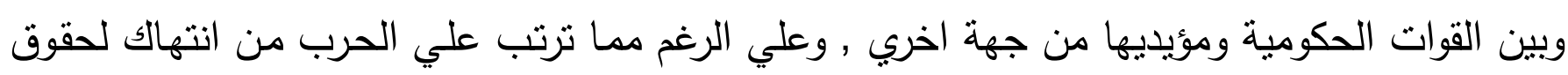


الأنسـان والاغتصـاب والسـرقة والخطف وتجنيد الأطفال وإغتصـاب الممتلكات ووجود عدد كبير من المشردين واللاجئين, إلا أن هذا الصراع ازداد تعقيدا بسبب التخخل الأجنبي في الأزمة.

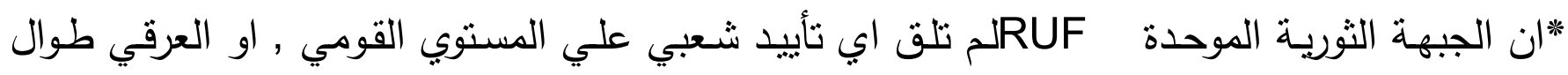

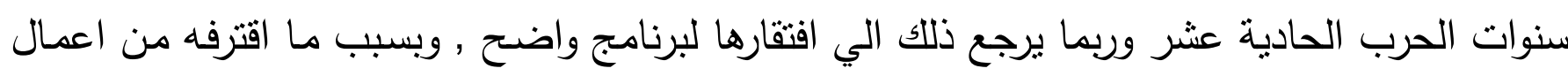
التخريب والقتل والتعذيب والخطف , وكذلك للقاعدة الاجتماعية التي ينتمي اليها افرداها وبسبب قياداتها غير المتعلقة. **إن مشكلة الأمن في سيراليون لا يمكن النظر اليها بمعزل عن مشكلة الأمن ولإستقرار في دول الجوار بغرب افريقيا وخاصة غنينا ولبييريا المتاختمين لها. وعلي الرغم من ان سيراليون ليست دولهن فئل فرانكوفونيه

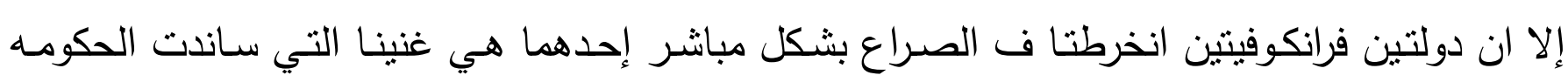
الثرعيه في سبراليون والثانيه هي بوركينافاسو التي كانت تؤيد المتمردين وتقوم بتدريبهم وتقديم الدعم

لهم.

*لم يرق اهتمام كل من الولايـات المتحدة الأمريكية وفرنسـا بالأزمـة في سيراليون الي نفس اهتمامها بالأزمات الأخري في الاول الأفريقية. أنه لا يوجد حل هسري فقط لإمهاء الصراع بين الأطراف المعنية وانما سيتظلب الآمر سنوات طويله



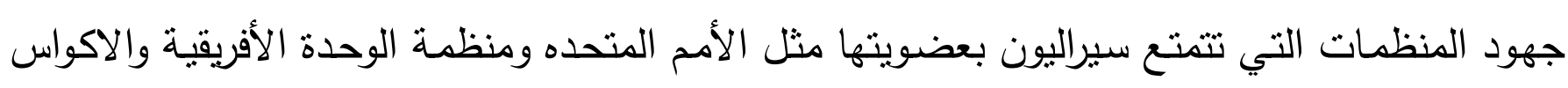

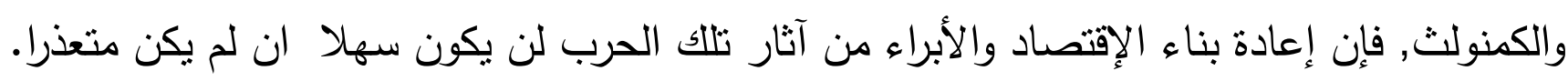
*لا شك ان محادثات السـلام التي تمت تحت رعاية الأكواس تعتبر بداية ايجابيه, برهن نجاح الجهود الأقليمية في تسوية الأزمة في سيراليون علي قدرة الدول الأفريقية علي حل مشكلاتها.


افضل الخيارات لكي تلحق سيراليون بركب التقدم, لأن هذا التراجع سيؤدي, اذا ما حدث, الي تعريض تُبه النظام لهزات عنيفه قد تؤدي الي تقويق دعائم استقراره. قلب هذه المسأله. ان الحرب في سيرالييون جاءت نتيجه اغتراب الثباب عن بلادهم ورؤيتهم لبعض الافلام المتكرره التي تركز علي الحرب والارهاب كما يحدث في افلام رامبوا ،هذا بجانب وجود دعم مادى ومعنوى للجبهه

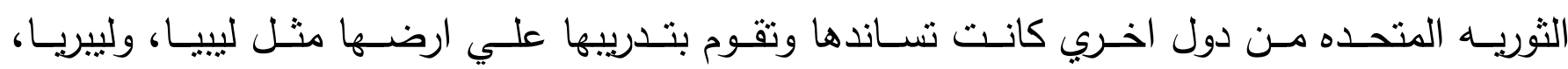


وبوركينافاسو وبالنظرالى ازمه سيراليون نجد ان انهيار الدوله وزيادة الاهمال وعدم القدره علي تقديم اي

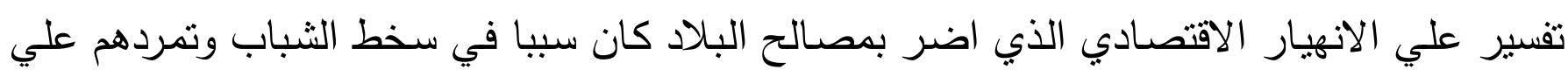

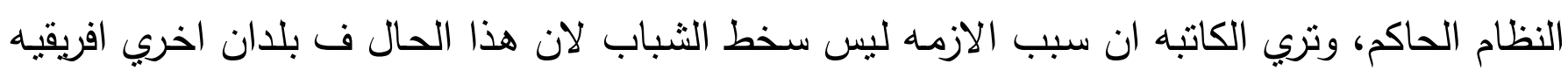

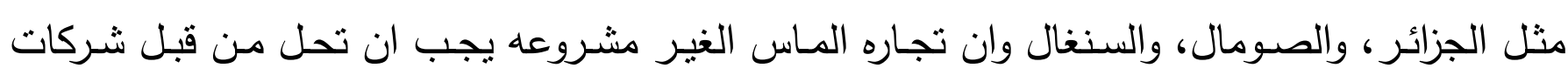

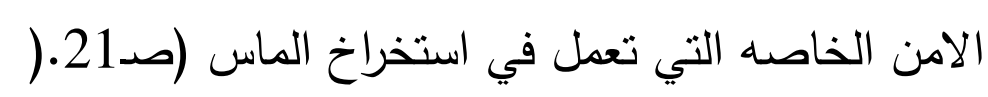

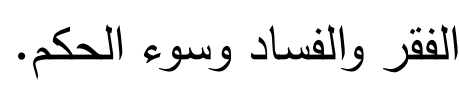
ان تقرير مكتب المبادرات الانتقاليه يقدم وجهة نظر مختلفه عن البدء في التتخيل الفعلي في استخراج

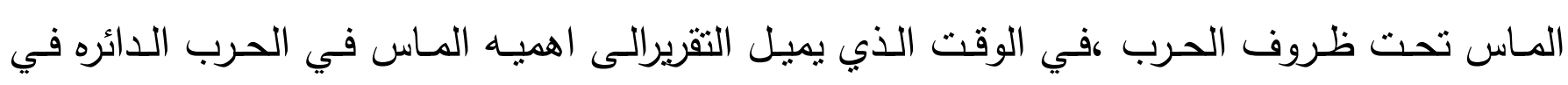
سيراليون وهذا يعكس وجهه نظر اخري.

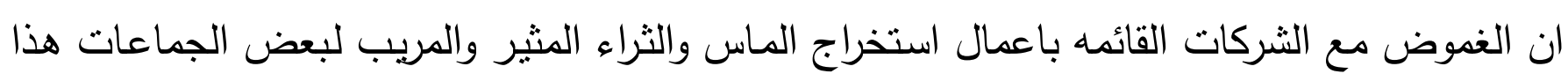

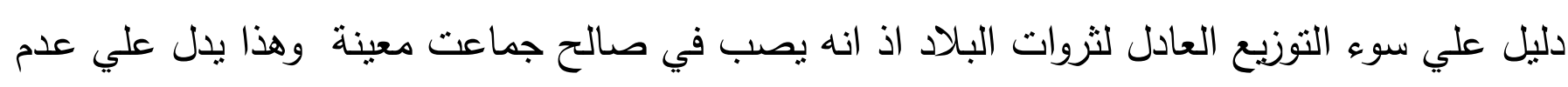

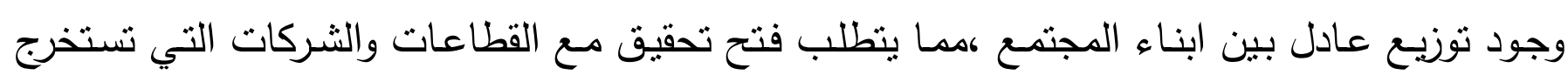

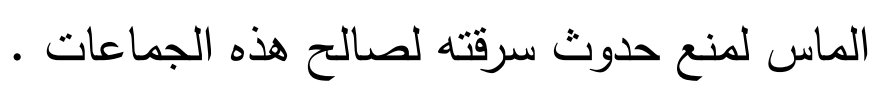

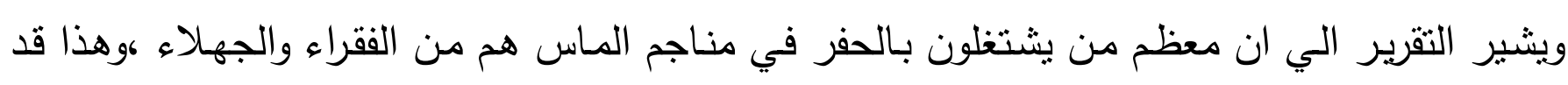

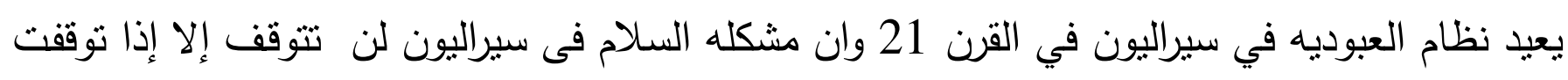



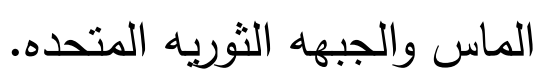
ويثير هذا التقرير الخاص للخبراء المعنيين من قبل مجلس الامن الدولي الذين تولي مهام فرض التهات

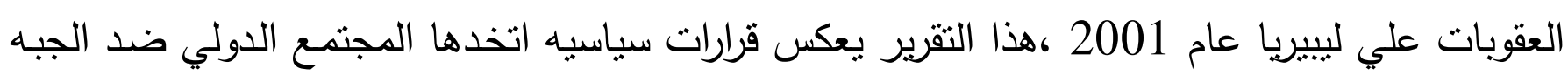

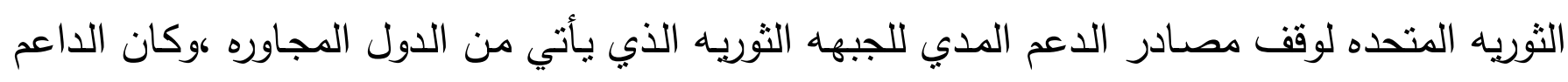



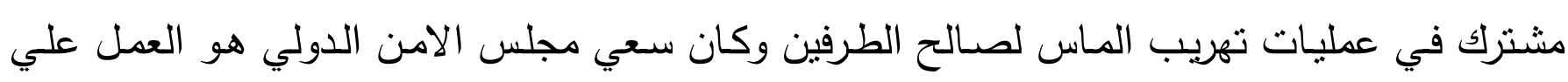

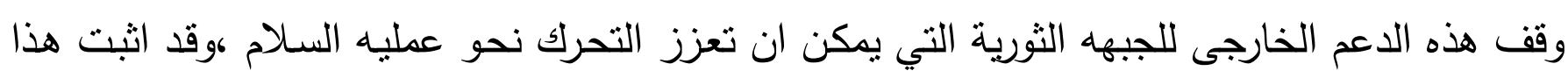
النقرير انه الي حدا كبير صحيح ، ووكلت هذه المهام الى القوات الاوكرانيه والهنديه وجنوب افريقيا

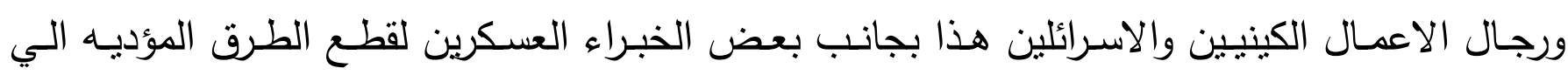

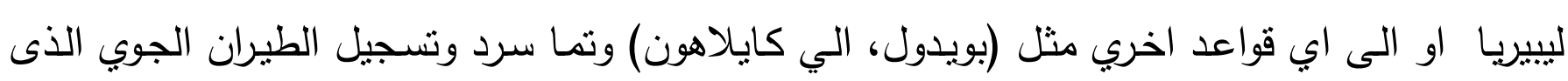


كان من الصعب السبطره عليه، والذى تسبب بعد ذللك في الهجوم علي مدينه فريتاون من قبل الجبهه



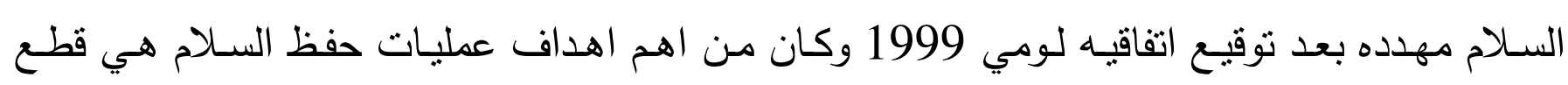
مصادر الامداد التي تأتي الي الجبهه الثوريه المتحده. ملخص باديوتيي او انهيار الدوله. يعتبر المساس هو احدي الوسـائل الهامـه في تمويل النزاع المسلح، وبخاصـه في المراحل الاخيره من

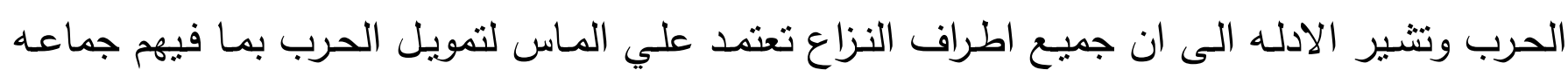

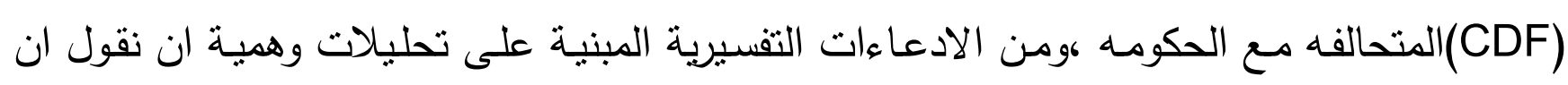
الحرب كانت تحت اسم قاتلوا من اجل الماس ولكن هذه تفسيرات افتراضيه اكثر منها تحليلات تجريبيه، اذ دخلت البلاد في كارثذه حقيقيه علي يد مجموعه من المتمردين لديهم تدريب عالي في فنون القتال

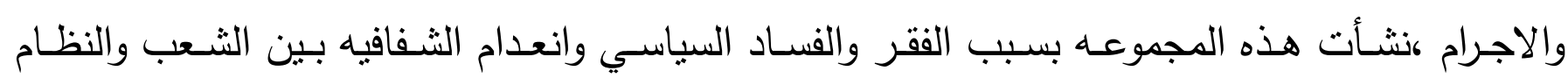
الحاكم. 
References:

First: Arabic language sources:

1Scientific Theses:

A- Ahmed Ibrahim Mahmoud Abdel-Aty, The Civil War Phenomenon in Africa (Master Thesis, Institute of African Research and Studies, Cairo University, 2000.(

Secondly, the publications in Arabic:

A-Dr. Raja Ibrahim Selim, Sierra Leone, and Out of Crisis (Cairo: Institute for African Research and Studies, Cairo University, special court publication, No. 57,2000.(

B- The Ministry of Information, the State Information Service, "Sierra Leone, between democratization and the return to military rule," a series of contemporary international studies (Cairo: The State Information Service, Ministry of Information, No. 108, December 1997.(

Second, the sources of the foreign language:

Artiecal (s) -1

williams, Alfred Bzack "Sierraleon the political economy of civil, 1991 -1998", third world - A Quartely (Taylor \& Francis, Ltd, Vol. 20, no1,1999(

Hanlon, Joseph "Is th International Community Helping to Recreate the Preconditions for War in Sierra B Leone?", The Round Table (London: Taylor \& Francis Group, Vol. 94, No. 381, September2005(

Chege, Michael "Sierra Leone: The State that Came Back from -c Dead" Th Washington Quarterly (Center for Strategic and International Studies and the Massachusetts Institute The of Technology, Vol.

25, No. 3, 2002.(

D- Le Billon, Philippe "The Political ecology of war: natural resources and armed conflicts" Political Geography (Elsevier- Sience Ltd, Vol. 20, no, 5,2001.(

Hanlon, Joseph "Is the International Commuity Helping to Recreate the Pre-Conditions-E forWar in Sierr Leone" UNU World Institute for Development Economics Research ", United Nations University, Helsinki, Finland, no.50,2005((

Richards, Paul The Political Economy of Internal Conflict in Sirra Leone, Working Paper-A A21 (Netherlands: Institute of International Relation, Clingendael, Conflict Reserarch Unit, Working Paper Series, August2003(

Other-3

Bellows, John "War and Local Institutions Sierra Leone", (Dhttp: // www.sscnet.ucla.edu-A /polisci/wgape/papers/10_BellowsMiguel.pdf, April 2006( 